\title{
International arbitration and the lex arbitri
}

\author{
Jacomijn J van Haersolte-van Hof*, Erik V Koppe ${ }^{\dagger}$
}

\begin{abstract}
The Transatlantic Trade and Investment Partnership (TTIP) between the EU and the US will be the most significant of the free trade agreements (FTAs) that the EU and its Member States is contemplating with third states. FTAs generally envisage arbitration as the preferred method for dispute resolution not only between the contracting parties but also between a contracting party and a private investor. Generally, a choice for arbitration entails application of a lex arbitri, which governs the arbitral procedure and provides safeguards ensuring the proper conduct of arbitration proceedings. While the existence and relevance of a lex arbitri is considered self-evident in relation to international commercial arbitration, there is not a similar understanding when it comes to inter-state arbitration or arbitration between states and private parties, i.e. mixed arbitration. This paper posits that inter-state arbitrations are generally subject to public international law, since the adjudicative and the prescriptive jurisdiction of host states are limited by general rules of customary international law. Further, this paper posits that mixed arbitrations, which are not governed by a stand-alone system (such as ICSID or arguably the Iran-U.S. C.T.), nowadays appear to be governed by national arbitration laws. Therefore, if the envisaged mixed arbitration system in the TTIP and other FTAs is to function as a stand-alone regime, independently from national arbitration laws and without interference from national courts, specific regulations in these treaties will be necessary.
\end{abstract}

\section{KEY REFERENCES}

- Draft Transatlantic Trade and Investment Partnership (TTIP) between the US and the EU

- Dutch Arbitration Act, Code of Civil Procedure, Book IV (1986) [Wetboek van Burgerlijke Rechtsvordering]

- UNCITRAL Model Law on International Commercial Arbitration, United Nations Commission on International Trade Law (1985, amended 2006)

- Dutch Bill Regarding the Applicability of Dutch Law to the Awards of the Tribunal Sitting in The Hague to Hear Claims Between Iran and the United States (1983)

- (ICSID) Convention on the Settlement of Investment Disputes between States and Nationals of other States (1965)

* Jacomijn J van Haersolte-van Hof, Director General, London Court of International Arbitration (JvH@lcia.org).

+ Erik V Koppe, Assistant Professor of Public International Law, Leiden Law School, and the Grotius Center for International Legal Studies (E.V.Koppe@law.leidenuniv.nl).

(C) The Author 2015. Published by Oxford University Press. All rights reserved.

For Permissions, please email: journals.permissions@oup.com 
- Chagos Marine Protected Area Arbitration (Mauritius v UK), PCA, Reasoned Decision on Challenge, 30 November 2011

- Occidental Exploration and Production Company $v$ Republic of Ecuador, Court of Appeal of England and Wales (2005)

- Gould III, Ministry of Defence of Iran v Gould Incorporated (formerly Hoffman Export Corporation) and ors, US Court of Appeals (1989)

- British Petroleum Exploration Company (Libya) Limited v Libya, Award (1973)

- Saudi Arabia v Arabian American Oil Company (Aramco), Award (1958)

\section{INTRODUCTION}

In February 2013, the European Union (EU) and the United States (US) commenced negotiations for a Transatlantic Trade and Investment Partnership (TTIP). ${ }^{1}$ This partnership aims to remove trade barriers between the contracting states and seeks to facilitate private investment by providing investment protection. The TTIP will be the most significant of all Free Trade Agreements (FTAs) which the EU and its Member States have negotiated over the last few years, such as the FTAs with South Korea and Singapore, ${ }^{2}$ and is currently negotiating with other states (such as Canada, China, and Japan). ${ }^{3}$

The FTAs negotiated by the EU so far also provide for dispute settlement clauses. The EU/South Korea FTA provides for arbitration as one of the methods of dispute settlement between the Contracting Parties (Article 14 and Annex 14B and C) and so do the draft EU/Singapore FTA (Article 15 and Annex 15A and B) and the envisaged Comprehensive Economic and Trade Agreement (CETA) between the EU and Canada. Further, the EU/Singapore FTA (future Article 9) and the CETA also envisage arbitration as one of the methods of dispute settlement between investors and states. ${ }^{4}$

1 Please note that the research for this article was concluded in May 2014. Therefore, the article does not reflect the discussion to what extent the envisaged TTIP should provide for international arbitration to resolve disputes, in particular between investors and states, which discussion escalated in the course of 2014. See, for example, the European Commission's press release of 13 January 2015 following the publication of the results of an online consultation on investor-state protection and international arbitration between investors and states, which triggered 150,000 replies. According to Malmström, the Commissioner for Trade, the consultation shows there is huge scepticism against this form of dispute resolution. See < europa.eu/rapid/press-release_IP-15-3201_en.htm> (accessed 10 February 2015).

2 FTA between the EU and its Member States, of the one part, and the Republic of Korea, of the other part [sic], signed on 16 September 2010, entered into force on 1 July 2011, Official Journal of the European Union, L 127, Vol 54, 14 May 2011. The FTA with Singapore was completed on 20 September 2013 $<$ ec.europa.eu/trade/policy/countries-and-regions/agreements/> (accessed 5 February 2015).

3 See <ec.europa.eu/trade/policy/in-focus/ttip/> (accessed 5 February 2015).

4 See for an overview of the key features in relation to the investment provisions in the EU-Canada CETA: European Commission, Investment Provisions in the EU-Canada free trade agreement (CETA), 27 November 2013 <ec.europa.eu/trade/policy/countries-and-regions/countries/canada/> (accessed 5 February 2015). The EU and Canada have apparently agreed on clarifications of the key substantive provisions and have agreed to establish 'the most progressive system of investor-state dispute settlement yet agreed in any agreement'. This system is intended to 'ensure that the system is effective and efficient, whilst providing important procedural safeguards which will improve the control of the parties of the interpretation of the agreement and ensure that frivolous cases are discouraged or swiftly dismissed'. See also European Commission, Investment Protection and Investor-to-State Dispute Settlement in EU agreements; Fact Sheet, November 2013 <ec.europa.eu/trade/policy/accessing-markets/investment/> (accessed 5 February 2015). 
The choice for arbitration as the preferred method for dispute resolution between the EU, EU Member States, Contracting Parties, and investors appears to be unquestioned, at least when it comes to inter-state disputes. ${ }^{5}$ Indeed, over the past 20-30 years, arbitration has become a popular method for dispute resolution, both in interstate and in investor-state disputes. Yet, a choice for arbitration also entails application of a lex arbitri, ${ }^{6}$ which is the law that legitimizes or rather 'governs the validity of the arbitral process itself. ${ }^{7}$ The lex arbitri regulates, among other things, the issue to what extent disputing parties may resort to interim measures, to what extent parties may resort to domestic courts for 'supportive measures to assist an arbitration which has run into difficulties' and to what extent courts have 'supervisory jurisdiction over arbitrations. ${ }^{8}$ As such the lex arbitri contains safeguards ensuring the proper conduct of arbitration proceedings.

While the existence and relevance of a lex arbitri are considered self-evident in relation to international commercial arbitration, there does not appear to be a similar understanding when it comes to inter-state arbitrations or arbitrations between a state and a private party, such as an investor, so-called mixed arbitrations. ${ }^{9}$ Therefore, this article first seeks to clarify the relevance of the lex arbitri in general (Section 2). Subsequently, this article identifies the applicable lex arbitri in relation to inter-state arbitrations and mixed arbitrations and the scope and relevance of the lex arbitri to such proceedings (Sections 3 and 4), followed by a short conclusion (Section 5). Arbitration between states or investors on the one hand, and international organizations such as the EU on the other, will not be discussed.

\section{THE RELEVANCE OF THE LEX ARBITRI}

The relevance of the lex arbitri to arbitral proceedings is best illustrated by reference to its role and application in relation to international commercial arbitration.

5 In October 2013, the European Commission issued a paper seeking to rebut criticism against investorstate arbitration. The availability of investor-state arbitration was particularly criticized when arbitral proceedings were instigated by companies against Germany for its decision to phase out nuclear power generation (Vattenfall $v$ Germany) and against Australia for its decision to ban brand names on cigarette packs (Philip Morris v Australia). It is feared that (the threat of) investment arbitration will impact the ability of states to make legitimate policy choices and thus their right to regulate. See also European Commission, Investment Protection and Investor-to-State Dispute Settlement in EU agreements; Fact Sheet, 5-6; European Commission, Incorrect Claims about investor-state dispute settlement, 3 October 2013 <trade.ec.europa.eu/doclib/docs/2013/october/tradoc_151790.pdf> (accessed 5 February 2015).

6 It appears that the term was first coined by Mann: FA Mann, 'Lex Facit Arbitrum' in P Sanders (ed), International Arbitration; Liber Amicorum for Martin Domke (Martinus Nijhoff, The Hague, 1967), 160.

7 WW Park, 'The Lex Loci Arbitri and International Commercial Arbitration' (1983) 32 ICLQ 21, 23. The lex arbitri 'underpins and governs the arbitral process'; J Collier and V Lowe, The Settlement of Disputes in International Law; Institutions and Procedures (OUP, Oxford, 1999) 229, 230.

8 Steyn J in Paul Smith v H\&'S Holdings Inc, [1992] 2 Lloyd's Rep 127, at 130, as quoted in Collier and Lowe, ibid, 229; and N Blackaby, C Partasides, A Redfern and M Hunter, Redfern and Hunter on International Arbitration (5th edn OUP, Oxford, 2009) para 3.39.

9 According to Read, '[a]s with so many aspects of investment arbitration law, the precise contours of the importance of lex arbitri are still evolving'. P Read, 'Delocalization of International Commercial Arbitration: Its Relevance in the New Millennium' (1999) 10 Am Rev Int Arbitr 180, in CF Dugan and others, Investor-State Arbitration (OUP, Oxford, 2008) 91. 
International commercial arbitration is generally deemed to be subject to a national law, generally speaking the law of the state in which the arbitration is seated. Dutch arbitration law, for example, which is incorporated in the Dutch Code of Civil Procedure (DCCP), is applicable if the place of arbitration is situated within the Netherlands (section 1073 DCCP). ${ }^{10}$ The primacy of the seat as the connecting factor for the application of national arbitration law is based on the jurisdictional theory' with respect to arbitration, which 'maintains that arbitration is rooted in the sovereignty of States and their authority to prescribe methods for dispute resolution which may, or must, be adopted within their borders'. ${ }^{11}$ By locating the place of arbitration in the territory of a particular state, the parties thus choose to submit themselves to the arbitration legislation of that state. ${ }^{12}$

The primacy of the seat for the application of national arbitration law is not, however, a universally accepted rule. Although there is much to be said for according decisive weight to the seat, ${ }^{13}$ some authors and some court decisions advocate the notion of delocalized or floating arbitration. ${ }^{14}$ Proponents of this view generally rely on the 'contractual' or 'autonomy' theories in relation to arbitration. They argue that arbitration 'should be treated as an autonomous legal institution and not [forced] into inappropriate categories'. ${ }^{15}$ For the purposes of the present discussion, it probably suffices to consider that in the vast majority of cases as a matter of practice, if not of principle, it is the arbitration law of the seat that applies in relation to the control and support effected by the courts.

As mentioned above, the lex arbitri legitimizes the arbitration and thus supports and supervises the proceedings. Some of these prescriptive norms are mandatory and their effectuation is therefore exclusively controlled by national courts. Other norms are non-mandatory and may therefore also be contained in arbitration rules, which are incorporated by reference into contracts. In those cases, the effectuation of these norms is not necessarily performed by national courts, but may also be performed by the tribunal, or by third parties, notably arbitral institutions. The function of national

10 The territorial connection between the seat of the arbitration and the application of national arbitration law also underlies the general system of the UNCITRAL Model Law (UML) as evidenced by art 1 UML.

11 Collier and Lowe (n 6) 230, 231. See also Mann (n 5) 161-62.

12 See also Dugan and others who write (in relation to investor-state arbitration): 'The decision to designate a particular country as the place of arbitration may bring with it a choice of lex arbitri, importing to a large degree the mandatory (non-derogable) rules of the forum with regard to the conduct of arbitration, ethical standards for counsel and arbitrators, and other important legal standards.' And subsequently: '[T] he national courts and the law of the legal situs of arbitration control a losing party's attempt to set aside [an] award.' Dugan and others (n 8) 133, 636.

13 One could refer, for example, to the responsibilities imposed on the domestic courts with supervisory roles, who may otherwise be faced with the need to apply a different arbitration law than their own if the seat's law does not apply as a matter of course.

14 See J Paulsson, 'Arbitration Unbound: Award detached from the Law of its Country of Origin' (1981) 30 ICLQ 358. See also Park (n 6) 24-28. The 2011 revised French arbitration law explicitly recognizes that the jurisdiction of French courts acting in support of the arbitration extends not only to the traditional instances where the parties have selected France as the seat or French law as the law applicable to the procedure or, but also to circumstances in which a party 'is exposed to a risk of denial of justice', s 1505(4) French CCP. See also Collier and Lowe (n 6) 232-35. 
courts is therefore to be characterized as supportive rather than as supervising or controlling.

Although the potential role of national courts is multifaceted, modern arbitration laws generally seek to minimize the courts' influence and to give maximum weight to party autonomy. This is well-illustrated by the explicit provision in the Model Law of the United Nations Commission on International Trade Law (UNCITRAL Model Law or UML) that 'no court shall intervene except where so provided in this Law'. ${ }^{16}$ The goal and purpose are to aid if and where needed and desired, and to ensure that essential principles of due process are taken into account.

Broadly speaking, four more or less distinct phases can be distinguished when support or control by national courts is required. First, at the stage when a court is approached in contravention of an allegedly valid arbitration agreement, or by contrast, a tribunal is confronted with a defense that there is no valid arbitration agreement. Secondly, assistance may be required in connection with the constitution of the tribunal and the possible replacement or challenge of arbitrators. Thirdly, courts may be requested to issue interim measures, including requests for security. Fourthly, courts may be addressed to review arbitral awards and to aid in the enforcement thereof. ${ }^{17}$

\subsection{Review of jurisdiction}

First, although most national arbitration acts clarify that in principle tribunals have the right to rule on their own jurisdiction, ${ }^{18}$ national courts ultimately control whether parties have validly ousted the jurisdiction of national courts. ${ }^{19}$ After all, access to court, or rather 'an independent and impartial tribunal established by law', as laid down in Article 6 of the European Convention on Human Rights (ECHR), for example, is a fundamental right, and national courts must be able to assess whether the parties have indeed waived this right voluntarily and unambiguously. ${ }^{20}$ National laws do vary as to when this control can be implemented: only at the end of the arbitral proceedings or (also) before or during the proceedings. ${ }^{21}$ Obviously, the former system gives greater freedom to arbitrators.

16 art 5 UML.

17 See generally on the ways and stages of Court intervention throughout arbitration proceedings: Read (n 8) 104-05.

18 See, for example, s 1052(1) DCCP, which provides that tribunals have the power to rule on their own jurisdiction; s 1022 DCCP is the corollary of this provision and requires courts to declare that they have no jurisdiction if a party before it invokes the existence of an arbitration agreement. See also, arts 16 and 5 UML.

19 See, for example, s 1065(1)(a) DCCP, which provides that the absence of a valid arbitration agreement constitutes a ground for setting aside. See also art 40(2)(a)(i) UML.

20 Convention for the Protection of Human Rights and Fundamental Freedoms, as amended by Protocols Nos 11 and 14, and supplemented by Protocols No 1, 4, 6, 7, 12, 13, signed on 4 November 1950, entered into force on 3 September 1953, see <www.echr.coe.int $>$ (accessed 5 February 2015). See generally GJ Meijer, Overeenkomst tot arbitrage (The Arbitration Agreement) (Kluwer, Deventer, 2011) 33-90.

21 Compare s 1448 French CCP, which limits the role of the courts ('When a dispute subject to an arbitration agreement is brought before a court, such court shall decline jurisdiction, except if an arbitral tribunal has not yet been vested to hear the dispute and if the arbitration agreement is manifestly void or manifestly not applicable'). Consequently, when no arbitral tribunal has been constituted yet, the courts will be entitled to rule on the dispute only where a prima facie examination of the arbitration agreement 


\subsection{Constitution of the tribunal}

Second, assistance of a national court may be required in relation to the constitution of an arbitral tribunal. National courts may come to the aid of the parties in securing the appointment of the tribunal or members thereof, notably where one of the parties fails to cooperate. ${ }^{22}$ This is especially important where the parties have not selected a set of arbitration rules or an appointing authority that can perform this task. The corollary of this task is the ability to review the appointment of an arbitrator, in the form of challenge or removal proceedings. ${ }^{23}$

Appointing a (missing) arbitrator is clearly a constructive and supportive task, but goes beyond the mere assistance of the parties. The constitution of a tribunal is an important safeguard to a proper arbitral procedure. To this effect, although the precise formulation of the standard varies, rules and laws provide that arbitrators should be independent and impartial. ${ }^{24}$ In addition, whereas party autonomy requires that contractual requirements concerning the qualifications of the arbitrators are respected, the result may not be that one of the parties is in a privileged position in appointing arbitrators. ${ }^{25}$ These requirements form the basis of the review by institutions and/or courts in the context of challenge proceedings. Concerns-legitimate or otherwise-about appointed arbitrators may also be the prelude to a possible request for setting aside at the end of the arbitral proceedings on the basis that the tribunal was not constituted in accordance with the applicable rules, or even in violation of rules of public policy. ${ }^{26}$

Challenges are-to some extent unfortunately-an important feature of arbitration. In addition to being a fundamental issue, instituting a challenge may significantly impact the arbitration's time schedule and thus form a potential instrument for abuse. Although the number of decisions in the public domain is limited, challenges appear to occur with increasing frequency. The broad nature of the typical challenge grounds also means that it is difficult precisely to predict the outcome of a challenge request. This uncertainty is increased where institutions and courts have parallel jurisdiction over challenge requests, and may not apply the same standards. $^{27}$

establishes that such agreement is manifestly void or manifestly not applicable. When an arbitral tribunal has been constituted, the courts shall automatically defer the dispute to the tribunal, without prejudice to the parties' right to seek a review of the award at the end of the arbitral process. In Germany, however, whereas a similar rule applies once a tribunal has been appointed, the parties may actively procure a court decision to determine whether there is a valid arbitration agreement in the first place, see s 1032(2) German CCP ('Prior to the constitution of the arbitral tribunal, an application may be made to the court to determine whether or not arbitration is admissible').

22 See, for example, s 1027ff. DCCP, which nominates the Provisional Relief Judge of the District Court as competent to deal with a number of situations in which one or more arbitrators are not appointed. See also art $11 \mathrm{ff}$. UML.

23 See, for example, s 1033ff. DCCP ; see also art 13(3) UML.

24 See s 1033 DCCP; see also art 12 UML.

25 See s 1028 DCCP.

26 See s 1065 DCCP. (Dutch) case law confirms circumstances that would have justified a challenge may be relevant for determining whether due process and therefore public policy was breached in the way in which the award was made, Dutch Supreme Court, 18 February 1994, NJ 1994, 756 (Nordström/Nievelt Goudriaan \& Co), ECHR 26 November 1996, NJ 1997505 (Nordström/The Netherlands).

27 See, for example, the judgment of the District Court of the Hague in relation to the challenge of Prof Gaillard in 2004, which will be discussed further below. Ghana's request was first rejected by the 


\subsection{Interim measures}

Third, courts may play a supportive role in issuing interim relief in urgent situations, parallel to or instead of the tribunal. Illustrative in this respect are the Arbitration Rules of the International Chamber of Commerce (ICC Rules), which provide that unless otherwise agreed, the tribunal may order any interim or conservatory measure it deems appropriate (Article 28(1)). ${ }^{28}$ Before the tribunal is constituted and in appropriate circumstances thereafter, a party may also request a court to issue such measures (Article 28(2)). ${ }^{29}$ National law will typically accommodate such a system by confirming that national courts may have jurisdiction to issue interim relief, and specify the conditions. ${ }^{30}$ Enforcement of tribunal ordered measures may become an issue for the courts, but that presupposes that the tribunal has ordered a binding decision, presumably laid down in an award not a mere order.

\subsection{Review of the award}

Fourth, courts may play a dual controlling role at the end of the procedure. Whereas the losing party may seek the setting aside of the award, the winning party may seek court assistance in enforcing the award. The grounds for setting aside and refusal of enforcement are limited, and can be similar to each other. Typically, grounds for setting aside include review of the tribunal's jurisdiction, review of the appointment process, scope of the tribunal's mandate, due process and other issues of public policy. ${ }^{31}$ Sometimes other grounds may play a role, such as whether reasons have been provided. $^{32}$ The grounds for review of enforcement tend to be similar to the grounds for setting aside an award and are laid down in Article V of the 1958 New York Convention on Recognition and Enforcement of Foreign Arbitral Awards. ${ }^{33}$

The four areas addressed above are the main areas of interface between arbitration and the courts in so far as international commercial arbitration is concerned.

Permanent Court of Arbitration (PCA), which was the Appointing Authority vested with the right under the applicable UNCITRAL Rules to decide on the challenge, but partially upheld by the District Court of The Hague. District Court of The Hague, Decision of 18 October 2004 (Republic of Ghana v Telekom Malaysia Berhad), HA/RK 2004.667, (2005) 23(1) ASA Bull 186-93. An unofficial translation is available through <www.italaw.com $>$ (accessed 5 February 2015).

28 See also Article 25(1) and Article 25(2) of the Arbitration Rules of the London Court of International Arbitration (LCIA Rules).

29 See also Article 25(3) LCIA Rules.

30 See, for example, s 1022(a) DCCP, providing that the arbitral agreement shall not preclude a party from requesting the court to grant conservatory measures or a decision in summary proceedings.

31 See art 34 UML.

32 See, for example, s 1065(1)(d) DCCP. Review by a court within the framework of setting aside proceedings must be distinguished from rectification and correction (and sometimes interpretation) of an award by the tribunal itself. See, for example, arts 37 and 38 UNCITRAL Rules.

33 Convention on the Recognition and Enforcement of Foreign Arbitral Awards, signed on 10 June 1958, UNTS, Vol 330, 3. Art V provides that recognition and enforcement of an arbitral award may be refused on the basis of a number of grounds, namely (i) the invalidity of the arbitration agreement; (ii) flaws in the notification of the arbitration or a party's inability to present its case; (iii) the tribunal having exceeded its mandate; (iv) the fact that the award has not become binding or has been set aside; and the fact that the subject matter is not arbitrable or breach of public policy. For an overview of the relevant provisions under Czech, Swiss, US, Russian, and Indian law, see: V Balas, 'Review of Awards' in P Muchlinski, F Ortino and C Schreuer (eds), The Oxford Handbook of International Investment Law (OUP, Oxford, 2008) 1142-45. 
The next issue to be addressed is whether and if so, to what extent the involvement of sovereign states in arbitration impacts the mechanisms discussed above.

\section{INTER-STATE ARBITRATION}

\subsection{Inter-state arbitration and public international law}

\subsubsection{The law governing inter-state arbitrations}

It is generally accepted that inter-state arbitrations are subject to and governed by rules of public international law. ${ }^{34}$ Although most rules governing inter-state arbitrations are laid down in specific bilateral or multilateral treaties, such as the 1899 and 1907 Hague Conventions for the Pacific Settlement of International Disputes, ${ }^{35}$ or Annex VII of the 1982 United Nations (UN) Convention on the Law of the Seas (UNCLOS), ${ }^{36}$ it is arguable that in the 19th and in the 20th century, 'an international common law [has developed] upon which states may safely rely when they submit their disputes to arbitration'. 37 According to Carlston, these rules include, among other things, the obligation that 'the tribunal will observe the minimum procedural standards observed by courts of law generally, and that the judgment of the tribunal will be confined to the controversy submitted to it and will respect the law imposed upon the tribunal'. ${ }^{38}$

In the 1950s, the International Law Commission (ILC) of the UN attempted to codify and further develop the law relating to international arbitration. The ILC submitted Draft Conventions on Arbitration Procedure to the General Assembly in 1952 and $1953,{ }^{39}$ but when both drafts were met with criticism by the UN Member States, it decided to forego the format of a (binding) treaty and submit a set of

34 JG Merrills, International Dispute Settlement (5th edn CUP, Cambridge, 2011) 107. DD Caron, 'The Nature of the Iran-United States Claims Tribunal and the Evolving Structure of International Dispute Resolution' (1990) 84 Am J Int L 111, fn 29; JJ van Haersolte-van Hof and AK Hoffman, 'The Relationship between International Tribunals and Domestic Courts' in Muchlinski and others (n 28) 998, 1002.

35 The 1899 Hague Convention for the Pacific Settlement of International Disputes, which established the Permanent Court of Arbitration (PCA) in the Hague with 'the object of facilitating an immediate recourse to arbitration for international differences', also contained a set of arbitration rules, which would be applicable by default (art 20). Hague Convention (I) for the Pacific Settlement of International Disputes, signed on 29 July 1899, 1(2) Am J Intl L, Supplement: Official Documents, 1907, 107. In 1907, the Convention was replaced by the 1907 Hague Convention, which provided for a slightly amended set of arbitration rules. For a comparison between both conventions and verbatim records of the conference commission which discussed the revision of the 1899 Hague Convention I, see S Rosenne (ed), The Hague Peace Conferences of 1899 and 1907 and International Arbitration; Reports and Documents (T.M.C. Asser Press 2001) 223-85. Already in 1875, the newly established the Institut de Droit International drafted a set of arbitral rules for international arbitration (Session de la Haye-1875, Projet de règlement pour la procédure arbitrale internationale $<$ www.idi-iil.org $>$ (accessed 5 February 2015)).

36 UN Convention on the Law of the Seas, signed on 10 December 1982, entered into force on 16 November 1994, UNTS, Vol 1833, p 3.

37 KS Carlston, 'International Arbitration in the Postwar World' (1948) 13 Missouri L Rev 135. Similarly, 50 years later, Caron (n 32) 111-12.

38 Carlston, ibid, 136.

39 A/CN.4/59; Draft on Arbitral Procedure Prepared by the International Law Commission at its Fourth Session, 1952; and A/CN.4/76; Report of the International Law Commission Covering the Work of its Fifth Session, 1 June to 14 August 1953; Official Records of the General Assembly, Eighth Session, Supplement No 9 (A/2456). 
(optional) model rules for inter-state arbitration instead. The Model Rules on Arbitral Procedure (Model Rules) were adopted by the ILC in 1958, and taken note of by the General Assembly later that year. ${ }^{40}$ Although the Model Rules are therefore not binding as such, some of the norms reflected in these Model Rules, such as the rules $^{41}$ relating to the validity of an arbitral award, qualify as rules of customary international law and are thus binding upon all states. ${ }^{42}$ The precise demarcation of which provisions constitute customary international law, and which do not, is not straightforward.

\subsubsection{Support and supervision relating to inter-state arbitrations}

Although inter-state arbitrations are governed by rules of public international law (and as such by a lex arbitri), there is no general institutional framework which could provide support or which supervises the proceedings as in the case of international commercial arbitration. As a consequence of their sovereignty, states cannot be subjected to the jurisdiction of international courts or institutions, unless they have explicitly recognized the jurisdiction of such body.

The jurisdiction of the International Court of Justice (ICJ), ${ }^{43}$ for example, is limited to disputes between states which have accepted the jurisdiction of the Court pursuant to Article 36 of its Statute. Article 36 Statute ICJ provides that the Court may only hear disputes between states if both states have referred their dispute to the Court by means of mutual agreement (Article 36(1) Statute) or if one of the states has made a unilateral declaration pursuant to Article 36(2) Statute by which that state accepts the compulsory jurisdiction of the Court in advance.

In the 1920s and 1930s, the general lack of supervision over inter-state arbitrations was recognized as a deficiency of inter-state arbitrations. ${ }^{44}$ In order to remedy this defect, when the ILC was considering the law relating to international arbitration in the 1950s, it envisaged that the ICJ would have a supervisory (and sometimes supportive) role in various phases of the proceedings similar to the role of national courts under national arbitration laws. A supervisory role of the ICJ would 'safeguard the effectiveness of the undertakings voluntarily undertaken'. ${ }^{45}$ However, as

40 A/CN.4/117; Report of the International Law covering the work of its Tenth Session, 28 April to 4 July 1958. A/RES/1262 (XIII), adopted on 14 November 1958; Question of Arbitral Procedure, para 3.

41 It should be noted that the term 'rules' is used here and below in discussing international arbitration is used in a generic sense, and does not, or at least not necessarily relate to the term 'arbitration rules' used in international commercial arbitration as distinct from provisions contained in national law, and typically issued by an institution.

42 Caron generally refers to 'the customary international law that governs such processes' and 'customary practice'. One of the examples of such practice is the right of either party to declare an award a nullity 'when the arbitral process does not satisfy certain fundamental norms of fairness'. Caron (n 32) 111-12.

43 The ICJ was established in 1945 and is one of the principal organs of the UN. It succeeded the Permanent Court of International Justice (PCIJ) which was established in 1920.

44 Lauterpacht suggested in 1928 that a clause should be inserted in arbitration agreements providing for judicial review by the PCIJ, the ICJ's predecessor, in cases of disputes over the validity over arbitral awards. H Lauterpacht, 'The Legal Remedy in Case of Excess of Jurisdiction' (1928) Br YB Int L 118. See also the 1929 resolution of the Institut de Droit International, Session de New York - 1929, Extension de l'arbitrage obligatoire, through $<$ www.idi-iil.org $>$ (accessed 5 February 2015).

45 A/CN.4/76; Report of the International Law Commission Covering the Work of its Fifth Session, 1 June to 14 August 1953, para 27; see also para 29. 
discussed above, the ILC's original proposals for a convention on arbitral procedure, which provided for compulsory default jurisdiction of the ICJ, ${ }^{46}$ was met with severe criticism from states. The proposals supposedly reflected the ILC's desire to develop international law rather than codify custom and they

would distort traditional arbitration practice, making it into a quasi-compulsory jurisdiction procedure, instead of preserving its classical diplomatic character, in which it admittedly produces a legally binding, but final, solution, while leaving Governments considerable freedom as regards the conduct and even the outcome of the procedure, both wholly dependent on the form of the compromis. ${ }^{47}$

Indeed, the absence of any supervision by a court was in fact regarded as one of the attractive features of arbitration. ${ }^{48}$

The lack of a supportive or supervisory institutional framework in relation to inter-state arbitrations may frustrate arbitral proceedings, however, despite the fact that 'an agreement to arbitrate involves in substance an international obligation equivalent to a treaty obligation' ${ }^{49}$ In order to illustrate the complications generally discussed above, the four phases in arbitral proceedings identified earlier will be reviewed in turn from the perspective of inter-state arbitration.

3.2.2.1 Review of jurisdiction. The first phase of potential interface relates to the possible review of jurisdiction of the tribunal. Similar to international commercial arbitrations, it appears to be generally accepted that an inter-state arbitral tribunal is competent to decide on its own jurisdiction. Such competence even appears to qualify as a general principle of arbitral procedure as reflected in the arbitral rules contained in the 1907 Hague Convention (Article 73) and the 1958 Model Rules (Article 9). ${ }^{50}$ Failure to follow the terms of an arbitration agreement qualifies as excess of powers, which may lead to nullity of the ensuing arbitral award, as will be further discussed below. Public international law does not distinguish between 'lack of

46 States parties to the Draft Convention would automatically accept the jurisdiction of the ICJ and, as such would qualify as an acceptance of jurisdiction of the Court pursuant to art 36(1) of the Statute of the ICJ.

47 The overall criticism was summarized by Special Rapporteur Scelle, see A/CN.4/109 and Corr.1; Report concerning the Draft Convention on Arbitral Procedure adopted by the Commission at its Fifth session by Mr G Scelle, Special Rapporteur (with a 'model draft' on arbitral procedure annexed, 24 April 1957, paras 7,9).

48 See, for example, the Netherlands' observation to the original ILC Draft Convention in 1953, A/CN.4/ 76; Report of the International Law Commission Covering the Work of its Fifth Session, 1 June to 14 August 1953, p 235. The Netherlands' observations are also quoted in SM Schwebel, Justice in International Law; Selected Writings of Judge Stephen M. Schwebel (CUP, Cambridge, 1994) 226.

49 According to the ILC, such agreement entails a legal obligation 'to carry it out and, in consequence, to take all the steps necessary to enable the arbitration to take place and the dispute to be finally liquidated; and, similarly, to refrain from any action, positive or negative which would impede or frustrate that consummation'. A/CN.4/117, Report of the International Law Commission covering the work of its Tenth Session, 28 April to 4 July 1958, para 19. The ILC styled this 'the principle of non-frustration'.

50 See A/CN.4/59; Draft on Arbitral Procedure Prepared by the International Law Commission at its Fourth Session, 1952, p 63 (comment to art 11 of the ILC Draft Convention on Arbitral Procedure). Similarly A/CN.4/35; Memorandum on Arbitral Procedure, prepared by the Secretariat, para 44. 
jurisdiction (incompétence) and excess of jurisdiction (excès de pouvoir)' as is sometimes made under national law. ${ }^{51}$

If the parties have not consented to the jurisdiction of a supervisory court or other third party, then any dispute in relation to the jurisdiction of the tribunal must be resolved by the general means of (judicial) dispute settlement that are available to states.

3.2.2.2 Constitution of the tribunal. The second phase of potential interface is the constitution of an arbitral tribunal. If states have not agreed on a legal or institutional framework relating to the constitution of an arbitral tribunal, a dispute in this phase may paralyse the proceedings at an early stage. Therefore, in order to guarantee the establishment of a tribunal, a number of available inter-state arbitral rules provide for a role of a third party if parties fail to reach agreement as to composition of the tribunal. For example, Article 45 of the 1907 Hague Convention provides for a procedure which could ultimately involve one or more third states if the appointed arbitrators are unable to choose an 'Umpire', ie the president of the tribunal. ${ }^{52}$ Article 45 thus reflects the spirit of the age, which did not yet feature international courts, such as the Permanent Court of International Justice (PCIJ), or its successor the ICJ, which could play a supportive role if a dispute arose in relation to the constitution of a tribunal. Now that such bodies are available, arbitral instruments assign such role to the President of the ICJ, the Vice-President or the oldest member of the Court (Article 4 Model Rules), to the President of International Tribunal for the Law of the Sea (ITLOS; Article 3 Annex VII UNCLOS), or an appointing authority designated by the Secretary-General of the PCA (Articles 6-8 PCA Optional Rules).

Similarly, disputes may arise when the tribunal has already been established, for example, when a member of the tribunal is challenged by one of the parties for lack of independence and impartiality. ${ }^{53}$ The right to challenge an arbitrator arguably qualifies as a general principle of arbitral procedure, the denial of which 'will clearly lead to the nullity of any ensuing award'. ${ }^{54}$ Both the 1958 Model Rules and the PCA Optional Rules specifically provide for a legal and institutional framework to deal with challenges of arbitrators. Article 6 Model Rules provides that challenges may only relate to facts that have occurred after the constitution of the

51 A/CN.4/35; Memorandum on Arbitral Procedure, prepared by the Secretariat, para 56, with references to literature and case law in paras $57-58 \mathrm{a}$ (stating that 'The question is simply whether, under the terms of the agreement, the tribunal had authority to take the action, or to make the decision, which is in question.').

52 Art 45 provides that if the disputing parties must select 'a third Power' by 'common accord' who then should choose the Umpire. If the disputing parties cannot agree on the selection of this 'third Power', art 45 of the Hague Convention provides that each party then selects a different state, after which these two states choose an Umpire. If these two states cannot come to an agreement within 2 months' time, each of these state then presents two candidates taken from the list of arbitrators (under specific conditions), and the drawing of lots ultimately 'determines which of the candidates thus presented shall be Umpire'.

53 Another example may be the withdrawal of a member of the tribunal, which is a 'wrong under customary international law and the general principles of law recognized and applied in the practice of international arbitration' according to Schwebel. Such withdrawal may not 'as a matter of international legal principle, debar an international arbitral tribunal from proceedings and rendering a valid award'. See SM Schwebel, International Arbitration: Three Salient Problems, Hersch Lauterpacht Memorial Lectures (Grotius Publications Ltd, Cambridge, 1987) 144-296 (conclusion at 296). 
tribunal (except when there is a case of fraud or justifiable ignorance) and may involve the ICJ under certain circumstances. Articles 9-12 PCA Optional Rules prescribe that an arbitrator may be challenged 'if circumstances exist that give rise to justifiable doubts as to the arbitrator's impartiality or independence' while the ultimate decision on the challenge will be made by the designated appointing authority.

In the absence of a legal or institutional framework, a tribunal will have to improvise and establish how to deal with a challenge of an arbitrator and which legal framework it should use. This became evident in a recent procedure between the Republic of Mauritius and the United Kingdom under Annex VII UNCLOS. ${ }^{55}$ Since Annex VII does not regulate the challenging of an arbitrator, the tribunal proposed that the decision on challenge would be made by a majority vote of the other members of the tribunal, with a casting vote of the President, which was accepted by the parties. ${ }^{56}$ Subsequently, the tribunal ruled that the applicable (substantive) legal framework for deciding on the challenge was formed by the applicable rules on appointment of arbitrators, prescribing that arbitrators must enjoy 'the highest reputation for fairness, competence and integrity' (Article 2 Annex VII UNCLOS), 'supplemented by the law and practice of international courts and tribunals in inter-State cases'. 57 The Tribunal ultimately concluded that there were no 'justifiable grounds for doubting the independence and impartiality of that arbitrator in a particular case'. 58

3.2.2.3 Interim measures. The third phase of potential interface is the possibility to seek interim or provisional measures by parties to arbitral proceedings to preserve the respective rights of the parties. Of the above-mentioned international arbitral rules, the 1958 Model Rules, UNCLOS, and the PCA Optional Rules regulate such requests. These rules provide that the arbitral tribunals operating on the basis of these rules have the power to grant interim measures to preserve the respective rights of the parties (Article 20 Model Rules, Article 290 UNCLOS, and Article 26 PCA Optional Rules). If the tribunal has not yet been established, such power is sometime bestowed upon a third judicial entity, such as the ICJ (Article 1(2) Model Rules) or the ITLOS (Article 290(5) UNCLOS). ${ }^{59}$

55 Reasoned Decision on Challenge, in the matter of an arbitration before and arbitral tribunal constituted under Annex VII of the 1982 UN Convention on the Law of the Sea between the Republic of Mauritius and the United Kingdom of Great Britain and Northern Ireland, 30 November 2011, through <www. pca-cpa.org $>$ (accessed 5 February 2015) (Reasoned Decision on Challenge).

56 Reasoned Decision on Challenge, paras 13-14.

57 ibid para 165. The Tribunal found it not necessary to 'consider the principles and rules relating to arbitrators, developed in the context of international commercial arbitration and arbitration regarding investment disputes' (para 156) and decided that it would not consider the IBA Guidelines (para 165).

58 ibid paras 166, 184.

59 ITLOS recently granted a request for provisional measures from the Netherlands in relation to its dispute with the Russian Federation concerning the boarding and detention of the vessel Arctic Sunrise. ITLOS, Order of 22 November 2013, The 'Arctic Sunrise' Case (Kingdom of the Netherlands v. Russian Federation), Request for Provisional Measures, see $<$ www.itlos.org $>$ (accessed 5 February 2015) under Case No 22. 
A recent Order from the ICJ, however, suggests that states parties involved in arbitral proceedings may also seize a third judicial entity for interim or provisional measures after the tribunal has been established. On 17 December 2013, TimorLeste initiated legal proceedings against Australia before the ICJ and submitted a request for the indication of provisional measures in accordance with the ICJ's Statute and its Rules of Court. The dispute concerned the seizure and detention of documents and data from Timor-Leste by Australia earlier that month. These documents were taken from the premises of one of Timor-Leste's legal advisers in relation to a pending arbitration between Timor-Leste and Australia, which is administered by the PCA.

Australia argued that Timor-Leste's requests should be rejected, among other reasons because the tribunal had the express right to exercise the power to grant provisional measures based on its rules of procedure (which are based on the PCA Optional Rules) and the tribunal would be the more appropriate forum for dealing with Timor-Leste's request. ${ }^{60}$ By Order of 28 January 2014, however, the ICJ rejected Australia's submissions and claim to stay the proceedings, because it considered 'the dispute before it [between Timor-Leste and Australia]...sufficiently distinct from the dispute being adjudicated upon by the Arbitral Tribunal [in the Timor Sea Treaty Arbitration] ]. ${ }^{\circ 1}$ It subsequently proceeded with the procedure and granted a number of measures on 3 March 2014, after deciding that the ICJ had prima facie jurisdiction to hear this dispute on the merits. ${ }^{62}$

3.2.2.4 Review of the award. Finally, the fourth phase of potential interface relates to the possibility to review an arbitral award. Although the awards of arbitral tribunals are binding upon the parties to the dispute as a general principle of international ${ }_{\text {law }}{ }^{63}$ and non-compliance with an arbitral award will thus constitute a wrongful act entailing the responsibility of the state involved, ${ }^{64}$ the parties have the right to challenge the validity of the award. According to the ILC, such right would follow from customary international law. ${ }^{65}$ Only the 1958 Model Rules regulate the challenging of the validity of award. The Hague Conventions, UNCLOS, and the PCA Optional Rules remain silent on the matter.

60 Questions Relating to the Seizure and Detention of Certain Documents and Data (Timor-Leste v Australia), Verbatim Record CR2014/2, Public sitting, held on Tuesday 21 January 2014 at 10 a.m. at the Peace Palace, pp 37-48.

61 Questions Relating to the Seizure and Detention of Certain Documents and Data (Timor-Leste $v$ Australia), Request for the Indication of Provisional Measures, Order of 28 January 2014, p 2.

62 ibid paras 27-28.

63 A/CN.4/35; Memorandum on Arbitral Procedure, prepared by the Secretariat, para 96 (referring based to the fundamental principles of good faith and pacta sunt servanda). See also art 81 of the 1907 Hague Convention and arts 30 and 32 of the 1958 Model Rules.

64 Art 1 of the ILC Articles on the Responsibility of States for Internationally Wrongful Acts, which were annexed to A/RES/56/83 of 28 January 2002; see also Carlston (n 35) 135.

65 A/CN.4/76; Report of the International Law Commission Covering the Work of its Fifth Session, 1 June to 14 August 1953, para 17, in which the rules relating to nullity are presented as examples of the law of arbitral procedure, which is 'no more than a codification of existing law'. See also para 26. 
Article 35 Model Rules provide that a party may challenge the validity of an award on the following grounds:

a. That the tribunal has exceeded its powers;

b. That there was corruption on the part of a member of the tribunal;

c. That there has been a failure to state the reasons for the award or a serious departure from a fundamental rule of procedure;

d. That the undertaking to arbitrate or the compromis is a nullity.

These four grounds are similar to the grounds included in Article 27 of the 1875 Hague rules for international arbitration of the Institut de Droit International, ${ }^{66}$ and reflect customary international law according to the ILC. ${ }^{67}$

These four grounds bear a resemblance to the grounds which may be invoked by private parties in order to prevent recognition or enforcement of an arbitral award following international commercial arbitration proceedings as laid down in Article $\mathrm{V}$ of the 1958 New York Convention. The lack of coordination between the Model Rules and the New York Convention, which was drafted by another UN organ (the Committee on the Enforcement of International Arbitral Awards, which was established by the UN Economic and Social Council (ECOSOC)) at the same time, is striking though. Although the Model Rules focus on inter-state arbitrations and the New York Convention regulates the recognition and enforcement of foreign arbitral awards between private persons, the ILC did not exclude that the Model Rules could be used in arbitrations between non-state parties. Indeed, according to the ILC, the Model Rules could also be used in arbitrations between states and international organizations, in arbitrations between international organizations, and to a certain extent, to mixed arbitrations involving private entities. ${ }^{68}$

While customary international law thus entitles states parties to arbitral proceedings to challenge the validity of an arbitral award, and while there appears to be consensus as to the grounds for such challenge, the effectuation of such right before an international court or tribunal will depend on the explicit consent of the parties involved. In practice, this means that 'the declaration in effect becomes a justification for that state's refusal to comply with the award'. ${ }^{69}$ It is for that reason that the ILC

Just two years after its establishment, the Institut de Droit International, drafted a set of international arbitration rules in The Hague in 1875, which could be included in an arbitration agreement between states. Institut de Droit International, Session de la Haye - 1875, Projet de règlement pour la procédure arbitrale internationale <www.idi-iil.org $>$ (accessed 5 February 2015). Art 27 of these 1875 Hague rules provided: 'La sentence arbitrale est nulle en cas de compromis nul, ou d'excès de pouvoir ou de corruption prouvée d'un des arbitres ou d'erreur essentielle.' Please note that the 1899 and 1907 Hague Conventions did not contain such validity clause.

67 A/CN.4/76; Report of the International Law Commission Covering the Work of its Fifth Session, 1 June to 14 August 1953, paras 16-17. See also A/CN.4/92, Commentary on the Draft Convention on Arbitral Procedure Adopted by the International Law Commission at its Fifth Session, prepared by the Secretariat, UN, New York, 1955, 105-106.

68 A/CN.4/117; Report of the International Law covering the work of its Tenth Session, 28 April to 4 July 1958,82 , fn 16. 
drafted Article 36 Model Rules which provides for recourse to the ICJ if the parties cannot agree on the establishment of another tribunal.

If states have not included the Model Rules in their arbitration agreement, however (and have thus not consented to Article 36 Model Rules), and have not agreed upon any alternative arrangements, ${ }^{70}$ any dispute with respect to the validity of an arbitral award must be solved by the general methods of (judicial) dispute settlement that are available to them. Indeed, states may regard their dispute on the validity of an award as a new and separate dispute and may choose to submit this dispute to a new arbitration tribunal. This approach was not uncommon at the beginning of the 20th century. As a matter of fact, the very first award of an arbitral tribunal established under the auspices of the PCA in 1902 related to the character of an arbitral award rendered between the US and Mexico in 1875 (the Pious Fund of the Californias case). ${ }^{71}$ And in 1910, an arbitral tribunal administered by the PCA, rendered an award on the validity and annulment of arbitral awards in a dispute between the US and Venezuela (Orinoco Steamship Company case)..$^{72}$

Similarly, states may choose to submit a dispute as the validity of an arbitral award to the ICJ (so independently of the Model Rules), which indeed happened twice in the Court's existence. In 1957, Honduras and Nicaragua agreed to submit their dispute concerning the validity of an award rendered by the King of Spain in 1906 to the ICJ. ${ }^{73}$ And in 1989, Guinea-Bissau instituted proceedings before the ICJ against Senegal in relation to a dispute concerning the validity of an arbitral award delivered by a tribunal earlier that year. ${ }^{74}$ In this case, the Court's jurisdiction was not based on an ad hoc agreement but on the on the acceptance by both states of the

70 UNCLOS, for example, provides for a limited role of the (the President of) the ITLOS in relation to arbitration proceedings conducted under Annex VII of the Convention. Further, a number of multilateral treaties provide for some form of supervision, for example by providing that a new arbitral tribunal must be established in case of a dispute between parties in relation to the interpretation or execution of an arbitral award and the tribunal which rendered the award cannot decide on such dispute (see art 32(10)(b) of the 1992 Convention for the Protection of the Marine Environment of the North-East Atlantic (OSPAR)).

71 The Pious Fund of the Californias (The United States of America v Mexico), Award of the Tribunal, 14 October 1902, through <www.pca-cpa.org > (accessed 5 February 2015). For more examples of arbitral award review cases, see WM Reisman, Nullity and Revision; The Review and Enforcement of International Judgments and Awards (Yale University Press, New Haven, 1971) 159-60.

72 The Orinoco Steamship Company (The United States of America v Venezuela), Award of the Tribunal, 25 October 1910, through <www.pca-cpa.org> (accessed 5 February 2015). TG Nelson, Annulment of International Arbitration Awards: The Orinoco Steamship Case Sails On, 28 ASA Bulletin (2010), 205-06.

73 International Court of Justice, Case concerning the arbitral award made by the King of Spain on 23 December 1906 (Honduras v Nicaragua), Judgment of 18 November 1960, through <www.icj-cij.org> (accessed 5 February 2015). The Court upheld the award and ruled that it was not invalid due to excess of jurisdiction, essential error, and lack or inadequacy of reasons in support of the conclusions arrived at by the Arbitrator (22-28). Nicaragua had also argued that the constitution of the tribunal had been flawed because first, the requirements of the arbitration agreement had not been complied with, and second, that the arbitration agreement had lapsed before the King of Spain had been appointed arbitrator (17-21).

74 International Court of Justice, Case Concerning the Arbitral Award of 31 July 1989 (Guinea-Bissau v Senegal), Judgment of 12 November 1991, through <www.icj-cij.org> (accessed 5 February 2015). According to the Court, the arbitral award was not null and void, as claimed by Guinea-Bissau, for alleged failure to decide (as excès de pouvoir) or insufficient reasoning. 
compulsory jurisdiction of the Court pursuant to Article 36(2) of the ICJ Statute, as discussed above. ${ }^{75}$

If parties do not submit a dispute on the validity of an arbitral award to a new arbitral tribunal or to the ICJ, such disputes may remain unresolved. ${ }^{76}$ Such was the case, for example, when Argentina declared an arbitral award rendered by an arbitral tribunal in a case concerning a dispute between Argentina and Chile with respect to the delimitation of the Beagle Channel and sovereignty over a number of islands, null and void. ${ }^{77}$ The dispute was only solved after mediation of the Pope and further diplomatic negotiations. ${ }^{78}$

\subsection{Inter-state arbitration and national law}

As discussed above, inter-state proceedings are governed by public international law as a matter of principle. The applicable lex arbitri to inter-state arbitral proceedings must be found in any applicable treaty and/or customary international law. It is generally presumed that as a corollary thereof, inter-state arbitral proceedings are not subject to any national law or national courts. ${ }^{79}$ Strictly speaking, however, the fact that inter-state arbitrations are anchored in public international law as such does not necessarily preclude that inter-state arbitrations are subject to the jurisdiction of a national state, ie the jurisdiction of the host state. After all, as set out in Section 2, the jurisdictional theory is based on the notion that arbitration is rooted in the sovereignty of States and their authority to prescribe methods for dispute resolution in such State. In theory therefore, the seat of an arbitral tribunal on the territory of a national state-irrespective of the identity of the parties to the proceedings-could trigger the applicability of that state's national arbitration law. ${ }^{80}$ As will be explained below, however, that is arguably not the case. The basis for the inapplicability of national arbitration law must be found in general rules of international law and not in the mere presumption that inter-state arbitration is subject to public international law.

The applicability of national arbitration legislation to inter-state arbitration proceedings was raised in the above-mentioned Annex VII UNCLOS arbitral proceedings between Mauritius and the United Kingdom. Mauritius argued, inter alia, that if

75 Case Concerning the Arbitral Award of 31 July 1989, Judgment, paras 22-24.

76 Please note, however, that states have a general obligation pursuant to Art 2(3) UN Charter to settle their international disputes by peaceful means.

77 According to Argentina, the arbitral award was null and void because: (i) Argentina's theses had been distorted; (ii) the tribunal had opined on disputed questions which had not been subjected to arbitration; (iii) there were contradictions in the reasoning of the tribunal; (iv) there were interpretation defects; (v) the tribunal had made geographical and historical errors; and (vi) there was an imbalance in the evaluation of the argumentation and evidence submitted by each party. Argentina-Chile: Exchange of Diplomatic Notes Concerning the Beagle Channel Arbitration (25-26 January 1978), 17 ILM 7281978.

78 See LA De la Fayette, Beagle Channel Dispute, Max Planck Encyclopedia of International Law, through $<$ www.mpepil.com $>$ (accessed 5 February 2015).

79 Merrills (n 32) 107S; Schwebel (n 51) 6.

80 Compare Mann, who stated in relation to private arbitrations: '[A]rbitrators are inevitably subject to the legislative jurisdiction of the country in which the tribunal functions. Whatever the intentions of the parties may be, the legislative and judicial authorities of the seat control the tribunal's existence, composition and activities. It is primarily the law of the seat that decides whether and on what conditions arbitration is permitted at all.' Mann (n 5) 161-62. 
the arbitration were to proceed with the challenged arbitrator, 'the tribunal would be at serious risk of being annulled by a court in the Netherlands' ${ }^{81}$ The Tribunal observed, however, that 'the Tribunal does not consider that there is any basis under [UNCLOS] for the application of the Netherlands Arbitration Act or the jurisdiction of the Dutch courts in these proceedings, ${ }^{82}$

Although the Tribunal's decision is in conformity with the general presumption that inter-state arbitral proceedings are not subject to national arbitration legislation, the presumed non-applicability of the arbitration laws of the Netherlands as included in the Dutch Code of Civil Procedure cannot follow from the silence of UNCLOS on the matter. After all, the jurisdiction of the Dutch courts and the scope of Dutch law follow, as a matter of principle, from the territorial sovereignty of the Kingdom of the Netherlands. Sovereignty of a state entails full jurisdiction over its territory, ie full legislative (or prescriptive) jurisdiction, enforcement jurisdiction and adjudicative jurisdiction, ${ }^{83}$ and restrictions upon the independence or sovereignty of states may not be presumed. ${ }^{84}$ Therefore, if two states choose to seat their arbitration in a foreign state, they are, irrespective of the contents of their arbitration agreement, ${ }^{85}$ exposed to the jurisdiction of that foreign state.

The jurisdiction of a host state is not unlimited, however. Although states have a wide margin of discretion to make and enforce legislation in their own territories, including the right of states to claim adjudicative jurisdiction in civil cases, ${ }^{86}$ the jurisdiction of states is limited by rules of public international law. First, the adjudicative

81 Reasoned decision on challenge, para 112 (quotes derived from Mauritius Memorial on Challenge).

82 Reasoned decision in challenge, para 170.

83 See International Court of Justice, Jurisdictional Immunities of the State, Germany v Italy: Greece Intervening, Judgment of 3 February 2012, para 57; and generally Permanent Court of International Justice, The Case of the S.S. 'Lotus', Judgment of 7 September 1927, Series A - No 10, 19. Sovereignty give each state 'the right to exercise [in its territory], to the exclusion of any other State, the functions of a State'. The Island of Palmas Case (or Miangas), United States $v$ The Netherlands, Award of the Tribunal, Permanent Court of Arbitration, 4 April 1928, 8.

84 ibid 18 .

85 See for example Article 8 of the Submission Agreement between Singapore and Malaysia dated 9 January 2012 by which both states submitted their dispute concerning railway land to an arbitral tribunal administered by the PCA. Article 8 regulated the applicable lex arbitri. It provided: 'The Parties agree that the lex arbitri shall be public international law and not the domestic laws of the Netherlands or any other country, and nothing in this Agreement shall be construed as a waiver of sovereign immunity from, or a submission to, the jurisdiction of the courts of the Netherlands or any other country on any issue whatsoever, whether substantive or procedural.' See The Railway Land Arbitration, Malaysia v. Singapore, Award of the Tribunal, Permancent Court of Arbitration, 30 October 2014, 3. However, an arbitration agreement between states cannot entail any obligations for the host state pursuant to the general principle that a treaty only creates rights and obligations for the states that are parties to it (pacta tertiis nec nocent nec prosunt), which is reflected in customary international law and art 34 of the Vienna Convention on the Law of Treaties. Vienna Convention on the Law of Treaties, signed on 23 May 1969, entered into force on 27 January 1980, UNTS, Vol 1155, No 18232. E David, 'Article 34; General Rule Regarding Third States', in O Corten and P Klein (eds), The Vienna Conventions on the Law of Treaties; A Commentary, vol I (OUP, Oxford, 2011) 888.

86 See, for example, C Ryngaert, 'Universal Tort Jurisdiction over Gross Human Rights Violations' (2007) 38 NYIL, s 3.5, on the compatibility of the exercise of universal tort jurisdiction (such as the US Alien Tort Statute) with public international law. 
jurisdiction of a state is limited by the customary rules of state immunity, ${ }^{87}$ as reflected in Article 5 of the 2004 UN Convention on Jurisdictional Immunities of States and Their Property (UN Immunities Convention). ${ }^{88}$ The law of state immunity does not appear to recognize exceptions in relation to inter-state proceedings (see, for example, Articles 10 and 17 UN Immunities Convention). Second, the prescriptive or legislative jurisdiction of states is similarly limited by customary rules of international law. The limits of the prescriptive jurisdiction of states are usually discussed in relation to the extra-territorial scope of legislation, such as with respect to anti-trust legislation, foreign corrupt practices legislation, environmental legislation, and nationality decrees. States have 'a wide measure of discretion' when it comes to 'the application of their laws and the jurisdiction of their courts to persons, property and acts outside their territory'. ${ }^{89}$ Only when infringing upon the sovereignty of other states or breaches any other rule of public international law, public international law prohibits the application of a state's legislative jurisdiction. ${ }^{90}$

Arguably, however, public international law also limits the scope of a state's legislation, including its arbitration legislation, in relation to acts which occur within its own territory. After all, the principle of sovereignty entails a positive duty, namely 'the obligation to protect within the territory the rights of other States, in particular their right to integrity and inviolability in peace and in war. ${ }^{91}$ On the basis of this obligation, it is arguable that national arbitration legislation cannot apply to interstate arbitrations as a matter of international law and therefore cannot subject interstate arbitrations to the supervisory or supportive jurisdiction of national courts.

87 For arbitral proceedings conducted under the auspices of the PCA in the Netherlands, the 1999 Host Agreement concerning the Headquarters of the Permanent Court of Arbitration, signed on 30 March 1999, entered into force on 9 August 2000, Trb (Netherlands Treaty Series) 1999, 68, would limit the adjudicative jurisdiction of the courts of the Netherlands. The PCA has further concluded host state agreements with eight other states 'to establish a legal framework under which future PCA-administered proceedings can be conducted in the territory of the host country on an ad hoc basis, whether or not a permanent physical PCA presence has been established in that territory'. See < www.pca-cpa.org $>$ under 'About us'/Structure/Host Country Agreements (accessed 5 February 2015).

88 UN Convention on Jurisdictional Immunities of States and Their Property, opened for signature on 2 December 2004, has not entered into force yet, <treaties.un.org >. Annexed to A/RES/59/38 of 2 December 2004.

89 'Lotus' (n 81) 19.

90 It appears that general presumption against extraterritorial application of statutes, which is typically applied by the Supreme Court of the United States to establish whether an Act of Congress regulates conduct abroad, finds its origin in this general rule of public international law. According to the Supreme Court, the presumption against extraterritorial application of statutes 'serves to protect against unintended clashes between our laws and those of other nations which could result in international discord'. See EEOC v. Arabian American Oil Co., 499 US 244, 248, as quoted by the US Supreme Court in Kiobel v. Royal Dutch Petroleum Co. (Shell) 133 S. Ct. 1659 (2013), p 2.

91 The Island of Palmas Case (or Miangas), United States $v$ The Netherlands, Award of the Tribunal, Permanent Court of Arbitration, 4 April 1928, 9. See also the 1970 Declaration on Principles of International Law Concerning Friendly Relations and Co-Operation Among States in Accordance with the Charter of the UN, in which the General Assembly recognized the principle of sovereign equality of States as one of the seven fundamental principles of international law. According to the General Assembly, one of the elements of sovereign equality is: '(c) Each State has the duty to respect the personality of other States'. A/RES/2625 (XXV) of 24 October 1970. 
Inter-state arbitrations would thus have a privileged status under national arbitration law, ${ }^{92}$ preempting any discussion on the possible immunities of the parties to the proceedings before a domestic court. After all, if the arbitration legislation of the state in which the proceedings are held does not apply, the courts do not have jurisdiction as a matter of national law and therefore cannot even pronounce on the possible immunities of the parties involved. ${ }^{93}$

The inapplicability of national arbitration legislation to inter-state arbitration may be illustrated by a 2005 judgment from the United Kingdom. In Occidental/ Ecuador, the Court of Appeal observed (Lord Justice Mance):

We would agree that it is highly probable that courts could not exercise jurisdiction over an inter-state arbitration under Article VII [of the 1993 Bilateral Investment Treaty between the United States of America and the Republic of Ecuador which provides for arbitration in case of a dispute between the states parties to the treaty in relation to the interpretation or application of the treaty] (because it would not be based on an agreement to arbitrate within the meaning of the Arbitration Act 1996 or of the New York Convention and/or because of s.9(2) of the State Immunity Act 1978). ${ }^{94}$

Also, the attempt of the Dutch legislator to enact specific legislation relating to the qualification of certain awards rendered by the Iran-US C.T. (namely awards involving the claims of nationals) appears to imply that inter-state arbitrations (in this case between Iran and the US) as such do not fall under the scope of the Dutch arbitration legislation which was then in force. ${ }^{95}$ This legislative proposal, which will be

92 Schermers and Blokker make a clear distinction between privileges and immunities in relation to international organizations: "We shall use the word "privilege" for all cases in which local legislation is not, or is differently, applicable, and the word "immunity" for the immunity from [adjudicative] jurisdiction (unless indicated otherwise).' According to Schermers and Blokker, there is a 'general rule of international institutional law to the effect that national laws should not be applied to international organizations if they could affect the proper functioning of the organization'. HG Schermers and NM Blokker, International Institutional Law; Unity within Diversity (5th rev edn, Martinus Nijhoff Publishers, Leiden, 2011) paras $323,1606-08$. If such presumption applies to international organizations, such presumption should a fortiori apply to states. Compare also the presumption against extraterritorial application of Acts of Congress as applied by the United States Supreme Court mentioned above to prevent international discord. See Kiobel v. Royal Dutch Petroleum Co. (Shell) 133 S. Ct. 1659 (2013).

93 By that rationale, it appears that if courts are obliged to assess their adjudicative jurisdiction (under private international law) ex officio, as courts in the Netherlands are obliged to do, then a supervisory role of the courts of the host state will even be preempted if the parties to the proceedings would voluntary submit to the jurisdiction of the host state.

94 Occidental Exploration and Production Company v Republic of Ecuador [2005] EWCA Civ 1116 (9 September 2005), para 39 (emphasis added).

95 According to Caron, neither Iran nor the US anticipated the possibility of the applicability of Dutch arbitration legislation at the time of drafting and neither state 'expressed views on the legal system supervising the arbitrations involving official clams or interpretative disputes'. DD Caron, 'International Tribunals and the Role of the Host Country', in DD Caron and JR Crook (eds), The Iran-United States Claims Tribunal and the Process of International Claims Resolution; A Study by the Panel on State Responsibility of the American Society of International Law (Transnational Publishers, Ardsley, NY, 2000) 31. Earlier, however, Caron stated that US officials and Tribunal officials had expressed the belief that that if the circumstances arose, the state parties would act to block the subjection of proceedings involving official claims and interpretative disputes to the Dutch legal system.' Caron (n 32) 150. 
discussed further below, specifically sought to address the status of awards relating to claims from nationals by equating them with arbitral awards in the meaning of Dutch arbitration law. The proposal did not purport to address the status of inter-state disputes, which suggests that inter-state claims could not be equated with arbitral awards under Dutch arbitration law.

The inapplicability of national arbitration law to inter-state arbitrations, however, is generally not explicated in the law itself. In light of the above, in the absence of any explicit limitation in the law itself or in the relevant legislative history, a host state could choose to condition consent to host an inter-state arbitral tribunal in its territory $^{96}$ and either confirm the default rule of inapplicability of its national arbitration legislation, or alternatively expressly impose and regulate the applicability of certain parts of its legislation. ${ }^{97}$ If the consent serves to confirm the default position of non-applicability of national law, the express confirmation merely serves to clarify; if the consent seeks to deviate from the default position, and seeks to bestow jurisdiction on national courts, express consent is essential. Such consent could be expressed by means of a trilateral agreement between the host state and the states that are parties to the proceedings or the host state could express its consent unilaterally by adopting ad hoc legislation excluding or providing for jurisdiction of its courts.

\subsection{Conclusion}

It follows from the previous discussion that inter-state arbitration is subject to public international law. This is supported by practice of international arbitral tribunals and the ICJ involving disputes on the validity of arbitral awards as discussed in Section 3.2. Furthermore, general rules of customary international law limit the adjudicative jurisdiction of a state hosting an inter-state arbitration tribunal and arguably the prescriptive jurisdiction of that state. This means that an inter-state arbitration can only be subjected to the national courts of the host state or its national arbitration legislation, if the host state and the disputing parties explicitly agree thereto.

\section{MIXED ARBITRATION}

\subsection{Introduction}

While it can thus be said that inter-state arbitrations are exclusively governed by public international law and international commercial arbitrations are governed by national law (generally the law of the seat of arbitration), the emergence of mixed arbitration proceedings, ie proceedings between private parties and states raises the question as to the applicable lex arbitri pertaining to this form of arbitration.

This section first discusses the applicability of public international law as lex arbitri to mixed arbitrations. Secondly, and without seeking to provide an exhaustive suant to the Convention's Rules of Arbitral Procedure may only sit in the territory of a third Power with the latter's consent'. See also FA Mann, 'The Aminoil Arbitration' (1983) 54 Br YB Int L 215 stating that 'a truly international arbitration' would 'presuppose the consent of the host state.

97 See, for example, Caron who acknowledges the relevance of the willingness of the Netherlands to accept judicial review of inter-state claims, despite his previous statement that it is the intent of the parties involved which determines the applicable lex arbitri. Caron (n 32) 150-51. 
overview, this section discusses a number of hybrid regimes which have been designed for mixed arbitrations, with a specific focus on the regime established by the 1965 Convention on the Settlement of Investment Disputes between States and Nationals of Other States (ICSID Convention) and the regime underlying the establishment of the Iran-US C.T. Thirdly, this section discusses the applicability of national arbitration legislation to mixed arbitrations, which are not subject to the hybrid regimes discussed in the previous section.

\subsection{Mixed arbitration and public international law}

In the early years of mixed arbitrations, a number of arbitral tribunals ruled that proceedings between states and private entities could only be governed by rules of public international law and not by the law of the state of its seat. This view was based on the view that the sovereignty of the state party to the proceedings would prevent the application of national arbitration law to such proceedings. In 1958, an arbitral tribunal established pursuant to a concession agreement between Saudi Arabia and Arabian American Oil Company (ARAMCO case) discussed the rules applicable to the arbitration before it discussed the law to be applied to the merits of the dispute. The tribunal ruled:

Although the present arbitration was instituted, not between States, but between a State and a private American corporation, the Arbitration Tribunal is not of the opinion that the law of the country of its seat should be applied to the arbitration....

Considering the jurisdictional immunity of foreign States, recognized by international law in a spirit of respect for the essential dignity of sovereign power, the Tribunal is unable to hold that arbitral proceedings to which a sovereign State is a Party could be subject to the law of another State. Any interference by the latter State would constitute an infringement of the prerogatives of the State which is a Party to the arbitration. This would render illusory the award given in such circumstances. For these reasons, the Tribunal finds that the law of Geneva cannot be applied to the present arbitration....

By agreeing to fix the seat of the Tribunal in Switzerland, the foreign State which is a Party to the arbitration is not presumed to have surrendered its jurisdictional immunity in case of disputes relating to the implementation of the 'compromis' itself. In such a case, the rules set forth in the Draft Convention on Arbitral Procedure, adopted by the International Law Commission of the United Nations at its fifth session (New York 1955), should be applied by analogy. In considering that the arbitration, as such, is governed by the Law of Nations, the Arbitration Tribunal does not intend to apply this Law to the merits of the dispute, since the law governing the merits is independent of the law governing the arbitration itself. ${ }^{98}$ pp 155-56. 
Similarly, in 1977, an arbitral tribunal established pursuant to a deed of concession in relation to a dispute between Texaco Overseas Petroleum Company and the California Asiatic Oil Company on the one hand, and the Libyan Arab Republic on the other hand (TOPCO/CALASIATIC case) specifically discussed 'The Law Governing the Arbitration' (section IIB of the award) and ruled that the arbitration was governed by rules of public international law. First, the tribunal endorsed the arguments used by the arbitral tribunal in the ARAMCO case and considered that these reasons also applied to the case at hand. Further, the tribunal ruled that the presumption that the arbitration was governed by public international was strengthened by the fact that the parties had agreed that the parties 'have recourse, if need be, to the President of the International Court of Justice', which implied 'that it was their intention that this arbitration should come under the aegis of the UN and, therefore that the system of law governing this arbitration should be international law'. Finally, the tribunal observed that the parties had agreed upon rules of procedure for the proceedings, which included the provision that 'the arbitration shall be governed by these Rules of Procedure to the exclusion of the local law'. ${ }^{99}$

These decisions were made by arbitral tribunals and not by the courts or government of the states which hosted these tribunals. Whereas these decisions do not form state practice, on the non-applicability of national arbitration laws, they are nevertheless informative.

\subsection{Mixed arbitration and hybrid regimes}

\subsubsection{Introduction}

In view of the special characteristics of arbitrations between private entities and states and the different interests involved, in particular the interest of private parties to be able to enforce an award, stand-alone regimes have been developed under public international law, which rely on national law for particular purposes. As such, these stand-alone regimes qualify as hybrid regimes. This section discusses the regime established pursuant to the 1965 ICSID Convention (Section 4.3.2) as an example of a multilateral hybrid regime, and the regime of the Iran-US C.T., which was established in 1981 as an example of an ad hoc hybrid regime (Section 4.3.3). Other hybrid regimes, such as the regional hybrid regime established pursuant to the North American FTA which entered into force in 1994, will not be discussed.

International Arbitral Tribunal, established pursuant to Clause 28 of the Deeds of Concession between the Government of the Libyan Arab Republic, on the one hand, and California Asiatic Oil Company (CALASIATIC) and Texaco Overseas Petroleum Company (TOPCO), on the other hand, Award on the Merits, Geneva, 19 January 1977, paras 13-16, 17 ILM 1978, pp 8-9. In the same year, another tribunal established in relation to the dispute between the Libyan American Oil Company (LIAMCO) and Libya determined that the tribunal would be 'guided as much as possible by the general principles contained in the Draft Convention on Arbitral Procedure elaborated by the International Law Commission of the United Nations in 1958 [sic]'. According to the tribunal, it was 'an accepted principle of international law that the arbitral rules of procedure shall be determined by the agreement of the parties, or in de default of such agreement, by decision of the Arbitral Tribunal, independently of the local law of the sea of the seat of arbitration'. However, the tribunal did not come to an express finding as to the law governing the procedure as in the ARAMCO and TOPCO-Libya cases. Award of the Tribunal, in the Dispute between LIAMCO and the Government of the Libyan Arab Republic relating to Petroleum Concessions 16, 17 and 20, 83-84, 20 ILM 1981, 43 or 62 ILR 140. 


\subsubsection{ICSID}

The ICSID Convention of 1965 establishing a hybrid regime for regulating mixed arbitrations ${ }^{100}$ was concluded under the auspices of the World Bank and provides for the establishment of an International Center for the Settlement of Investment Disputes (ICSID). The Convention is supplemented by the ICSID Arbitration Rules. States may agree to ICSID arbitration by consenting to arbitration directly in a contract, or by consenting to ICSID arbitration in a Bilateral Investment Treaty (BIT), triggered by the request of a national from the other Contracting Party. In the latter scenario, a prerequisite is that both state parties involved have ratified the BIT as well as the ICSID Convention. ${ }^{101}$

Article 26 of the ICSID Convention provides that consent to arbitration under the Convention excludes any other remedy. This provision serves to confirm the self-contained nature of ICSID proceedings and ensures non-interference with the ICSID process once it has been instituted. ${ }^{102}$ The Convention provides for an independent set of rules regarding the constitution of arbitral tribunals, the powers and functions of arbitral tribunals, including the power to recommend provisional measures and review of awards.

Of particular interest for the present discussion is the right of either party to request annulment of an award on the basis of one or more limited grounds provided in Article 52 ICSID Convention. These grounds are largely similar to the grounds which were laid down in Article 35 of the 1958 Model Rules, ${ }^{103}$ and similar to the grounds for annulment contained in national arbitration laws and the UML. ${ }^{104}$ Article 52 further provides that an ad hoc committee of three persons shall be established which will decide on the requests for annulment. So whereas the ILC's proposal to empower the ICJ to decide on claims relating to the validity of an arbitral award met with strong resistance of the Member States of the UN, as was discussed above, the attribution of jurisdiction to an ad hoc committee to review arbitral awards under Article 52 was accepted without difficulty. Finally, Article 53 ICSID Convention confirms that an award shall not be subject to appeal or any

100 Dugan and others qualify ICSID as a 'self-contained procedural system, which is normally considered a-national, independent of any particular legal situs'. Dugan and others (n 8) 91.

101 Art 25(1) ICSID Convention provides: ' $\mathrm{t}$ ] he jurisdiction of the Centre shall extend to any legal dispute arising directly out of an investment, between a Contracting State (or any constituent subdivision or agency of a Contracting State designated to the Centre by that State) and a national of another Contracting State, which the parties to the dispute consent in writing to submit to the Centre.'

$102 \mathrm{CH}$ Schreuer, with L Malintoppi, A Reinisch and A Sinclair, The ICSID Convention: A Commentary (2nd edn, CUP, Cambridge, 2009) 351.

103 Both art 35 Model Rules and Art 52 ICSID Convention provide that an award may be challenged in case the tribunal has exceeded its powers (art 52 ICSID requires that the tribunal has manifestly exceeded its powers); in case of corruption on the part of a member of the tribunal, departure from a fundamental rule of procedure; and failure to state the reasons on which the award is based. The provisions differ somewhat insofar as the Model Rules refer to the nullity of the agreement to arbitrate and the ICSID Convention to flaws as to the constitution of the tribunal as grounds for review.

104 As was mentioned above, it is interesting to consider that the grounds for annulment were based on the ILC draft system which was intended to apply to public international arbitrations and not modelled on the New York Convention grounds for the refusal of recognition and enforcement of international commercial awards. The NYC dates from 1958 and could have been used as a source of inspiration for the ICSID Convention, the idea for which was conceived in 1961 (Schreuer and others (n 99) ix). 
other remedy, for example by national courts, except as provided for in the Convention.

The self-contained nature of the ICSID regime does not mean that it is completely detached from national laws or review by national courts. Namely, Article 54 ICSID Convention requires Contracting States to recognize awards as binding and enforce the 'pecuniary obligations imposed' within its territories as if it were a final judgment of a court in that State. Combined with Article 55, which provides that Article 54 does not derogate from any protection of immunity that a state might otherwise rely on, the effect of these provisions is that state courts will have some role in enforcing ICSID Awards, if this becomes necessary, ${ }^{105}$ even though it does not allow for an actual review at the enforcement stage such as that provided by the New York Convention.

The ICSID Convention thus qualifies as a hybrid system providing for rules governing mixed arbitration proceedings under public international law but referring to national law for recognition and enforcement of awards.

\subsubsection{Iran-US C.T.}

A second example of a unique arbitration mechanism is the Iran-US C.T. This Tribunal was established in 1981 in The Hague pursuant to the Declaration of the Government of the Democratic and Popular Republic of Algeria (General Declaration) and the Declaration of the Government of the Democratic and Popular Republic of Algeria concerning the Settlement of Claims by the Government of the US and the Government of the Islamic Republic of Iran [Claims Settlement Declaration (C.S.D.)], collectively referred to as the Algiers Accords. ${ }^{106}$ Pursuant to Article II of the Claims Settlement Declaration, the jurisdiction of the Tribunal is limited to three categories of claims: (i) claims of nationals of the US against Iran and claims of nationals of Iran against the US (claims of nationals); official claims of the US and Iran against each other arising out of certain contractual arrangements between them (official claims); and disputes between the US and Iran in relation to the interpretation and application of the General Declaration and the Claims Settlement Declaration (interpretative disputes).

These disputes were to be submitted before an 'international arbitral tribunal' (Article II(1) C.S.D.) having its seat in The Hague (Article VI(1) C.S.D.). The Tribunal was to conduct its business in accordance with the UNCITRAL Arbitration Rules, as modified by the Parties (Article III(2) C.S.D.). One of the provisions amended concerned the applicable law. Rather than referring to the law chosen by the parties or determined by the tribunal on the basis of conflict of laws rules, Article 33 of the Tribunal Rules of Procedure refers to 'such choice of law rules and principles of commercial and international law'. review was intended also to exclude a review based on public policy, practice in this respect has been somewhat different. Schreuer and others (n 99) 1140-41; G Petrochilos, S Noury et al., 'ICSID Convention, Chapter IV, Section 6, Article 54 [Enforcement of the Award]' in LA Mistelis (ed), Concise International Arbitration (Kluwer Law International, Alphen aan den Rijn, 2010) 146-47. 
The establishment of the Iran-US C.T. in the Netherlands, however, led to confusion as to the extent to which the Tribunal's awards were subject to the jurisdiction of the Netherlands, and in particular should be deemed to be governed by Dutch arbitration law. It appears that neither Iran nor the US had 'fully anticipated or appreciated the possibility of Dutch supervision at the time the Accords were drafted. ${ }^{107}$ When the Netherlands, the US, and Iran failed to regulate the institution of the Tribunal by means of an express headquarters agreement, the Netherlands drafted legislation, a unilateral instrument, to remove any uncertainty (in particular for Dutch courts) as to the qualification of the arbitral proceedings and applicability of Dutch arbitration law. ${ }^{108}$ Whereas claims of nationals were considered to be of civil and commercial character and practice showed that in practice both the Tribunal and Iran assumed that Dutch arbitration law was applicable, ${ }^{109}$ doubt existed as to the formal legal characterization. After all, the Tribunal was established under public international law and nationals of the US and Iran were obliged to submit their claims before the Iran-US C.T. ${ }^{110}$

The Bill's basic position was that 'in so far as civil claims' were concerned (ie the claims of nationals), the Tribunal's awards, would, in view of its seat be subject to Dutch arbitration law and 'thus' enforceable under the New York Convention. ${ }^{111}$ However, the Tribunal's awards in these 'civil disputes' would not be fully subjected to Dutch arbitration law, but would be governed by a special, limited regime and by limited review by the Dutch courts. For example, the supervision of Dutch courts was limited to setting aside proceedings on the basis of two grounds only: breach of due process and reasons of public policy, both of which form part of the fundamental principles of the Dutch legal order. ${ }^{112}$ These grounds were considered relevant since the Tribunal's work took place within this Dutch legal order. ${ }^{113}$ As such, disputes in

Caron (n 92) 31. Caron writes that US officials had debated whether or not the arbitral process 'should be supervised by the Dutch legal system', or 'whether the arbitrations should be subject to a municipal system at all'. ibid 31-32.

108 Caron (n 92) 32. Ontwerp van Wet (Draft Bill), Toepasselijkheid van Nederlands recht op de uitspraken van het te 's-Gravenhage zetelende tribunaal inzake vorderingen tussen Iran en de Verenigde Staten (Applicability of Dutch law to the awards of the tribunal established in The Hague in relation to claims between Iran and the US), Kamerstukken II, 1982/83, 18000, no 2 (Parliamentary Documents, House of Representatives, parliamentary year 1982/83, 18000, no 2). For unofficial translations of the Bill, see Caron (n 92) 37-39; and Schwebel (n 51) 7-8, fn 8. See for the reasons for submitting the bill, Memorie van Toelichting (Explanatory Notes), Kamerstukken II 1982-1983, 18 000, no 3, p 6 (in Dutch).

109 The Tribunal had deposited its awards with the Registry of the District Court of The Hague, which is a requirement under Dutch law and Iran had submitted a request for setting aside of an award of the Tribunal. Explanatory Notes, ibid 6.

110 ibid 6-7. At first sight, the obligatory character of the chosen method of dispute resolution would conflict with art 17 of the Dutch Constitution which provides that no one can be denied access to court against his will. See L Hardenberg, De uitspraken van het 'Iran-United States Claims Tribunal' naar Nederlands recht bezien (The awards of the 'Iran-United States Claims Tribunal' under Dutch law), Nederlands Juristenblad, 11 February 1984, no 6, 168.

111 ibid 7. The Bill did not address the status of inter-state disputes (the official and interpretative claims).

112 Nota naar Aanleiding van het Verslag (Aide-Mémoire following parliamentary discussion), Kamerstukken II, 1983/84, 18000, no 5, 5. 
relation to the constitution of the Tribunal and the challenging of arbitrators were excluded from the supervision of the Dutch courts. ${ }^{114}$

The reasons expressed for imposing this limited regime were twofold. First, the legislator considered that the applicable UNCITRAL Arbitration Rules had been agreed upon by the US and Iran in an international treaty (the C.S.D.), which prevailed over Dutch (arbitration) law so that this arbitration agreement between the US and Iran could not be equated with an international commercial arbitration agreement. ${ }^{115}$ The legislator failed, however, to show that the parties' incorporation of the UNCITRAL Rules indeed sought to replace Dutch law as the lex arbitri. As will be discussed below, and in the absence of such intent, it is difficult to understand why the mere reference to the UNCITRAL Arbitration Rules should be seen to constitute intent to have these Rules apply exclusively. Second, the legislator was of the opinion that the then existing arbitration legislation had not been designed for the category of claims submitted to the jurisdiction of the Iran-US C.T. ${ }^{116}$

In the end, the draft legislation was aborted while being subject to final review by the Senate in 1984, apparently after Iran had expressed its discontent with the Bill. Although Iran had meanwhile submitted a total of 10 challenges to awards of the Tribunal, and thus apparently recognized the applicability of Dutch law to the proceedings, $^{117}$ it reversed its position in 1984 and withdrew all challenges. ${ }^{118}$ According to Iran, the Bill disregarded the international character of the tribunal, ${ }^{119}$ which Iran regarded as an international court, governed by public international law, and established to settle disputes between two states. Further, the Bill would adversely affect Iran's interest and was contrary to public international law since it interfered in a matter between two states. ${ }^{120}$

When Iran sought enforcement of an award of the Tribunal in the US in 1987 (Gould $v$ Iran), however, the issue of the character of awards of the Tribunal involving claims of nationals was again subject of discussion. By seeking enforcement of an award of the Tribunal in the US under the New York Convention, Iran effectively recognized the Dutch nationality of the relevant award, which the US pointed out in an amicus brief submitted during the enforcement proceedings. According to the US the awards of the Tribunal appeared to be valid and enforceable under Dutch law and could therefore be considered 'Dutch awards'. ${ }^{121}$

114 Notably, the constitution of the Tribunal and the challenge of arbitrators were deemed to be regulated by the UNCITRAL Rules precluding the need for Dutch court review. Explanatory Notes (n 105) 9.

115 Explanatory Notes (n 105), 7.

116 Explanatory Notes (n 105) 8.

117 Caron (n 32) 144-46.

118 Caron (n 32) 145; Caron (n 92) 32-33.

119 See also Lake and Dana who wrote in 1984 that although there are arguments both in favour and against 'Dutch jurisdiction', 'it would not be unreasonable to conclude that the Algiers Accords establish the Tribunal as a "denationalized" adjudicating body, whose actions are governed by the treaty creating it and by its own rules, but not by any national arbitral law.' WT Lake and JT Dana, 'Judicial Review of Awards of the Iran-United States Claims Tribunal: Are the Tribunal's Awards Dutch?' (1984) 16 L Policy Int Business 779, 771-79.

120 Excerpt of Letter From Mohammad I. Eshragh, Agent of the Islamic Republic of Iran to the Iran-US Claims Tribunal, to All Members of the First and Second Chambers of the Dutch Parliament, in: Caron (n 92) 40-42. 
The Court of Appeals for the 9th Circuit indeed confirmed in Gould v Iran that Tribunal awards in which nationals were awarded compensation were enforceable under the New York Convention. ${ }^{122}$ The decision partly focused on the alleged non-voluntary nature of the arbitrations before the Tribunal, and confirmed the view that the President of the US had the power to conclude arbitration agreements on behalf of his nationals. The Court also confirmed that the Algiers Accords satisfied the 'agreement in writing' standard of the New York Convention ${ }^{123}$ and that in any event Gould, in filing its claim and arbitrating it before the Tribunal, had 'ratified' the actions of the US.

Of particular interest is Gould's second defense against enforcement of the award in the US. Gould relied on Article $\mathrm{V}(1)(\mathrm{e})$ which provides that enforcement of an arbitral award can be denied if ' $[\mathrm{t}]$ he award has not yet become binding on the parties, or has been set aside or suspended by a competent authority of the country in which, or under the law of which, that award was made'. According to Gould, the Convention thus only applied to arbitral awards made in accordance with the national arbitration law of a State Party to the Convention. Therefore, Gould argued, the Tribunal award against Gould did not fall under the scope of the New York Convention, since the Tribunal award was made under public international law and not under any national law.

The Court of Appeals rejected this argument and considered that Article I, the provision setting out the Convention's scope of applicability does not contain any explicit wording to this effect. In addition, it considered that 'although it is a close question, the fairest reading of Convention itself appears to be that it applies to the enforcement of non-national awards' ${ }^{124}$ Articles I through IV of the Convention do not require the selection of an applicable national law. It is only in the context of the review pursuant to Article $\mathrm{V}$ that some standards are set by reference to national law, whereas other safeguards, notably the right to be heard and public policy, remain in place to guard against enforcement of otherwise unfair arbitration awards. (1990) 605 (Court of Appeals for the 9th Circuit). For an overview, see Kronke and others, Recognition and Enforcement of Foreign Arbitral Awards, A Global Overview, pp 29-31 (reporting on decisions on the New York Convention's inapplicability to 'permanent' arbitral tribunals, art 1(2) NYC). The Court appears to be consistent with previous judgments relating to the above-mentioned LIAMCO arbitration. Despite the 'internationalization' of the procedure, the claimant succeeded to have the award recognized under the New York Convention in France, Sweden, and the US. GR Delaume, 'Arbitration with Governments: “Domestic” v. “International” Awards' (1983) 17 Int Lawyer 690.

123 Gould relied on the judgment of the High Court of the England (Dallal v Bank Mellat, 1 All ER 239 (QB1986) for this argument, but the Court of Appeals rejected this argument. According to the Court of Appeals, the High Court's opinion had been 'mischaracterized'. After all, the High Court in Dallal did not rule on the question if it had jurisdiction under the New York Convention, but instead had engaged in a ruling on the merits of whether a Tribunal award would bar a proceeding in English courts as res judicata based on the same claim. Further, the question if parties had entered into an agreement in writing was assessed on the basis of the conduct of the parties in the arbitration and not on the Accords themselves. And finally, the High Court's discussion appears to be dictum. Iran v Gould, ibid para 33.

124 The Court referred in this context to the decision of the Dutch Supreme Court in Societe Européenne d'Etudes et d'Enterprises (SEEE) v Socialist Federal Republic of Yugoslavia (Dutch Supreme Court, 26 October 1973, NJ 1974, 361) in which case the Supreme Court reversed the Court of Appeals of The Hague, which had ruled that the District Court had erred in recognizing an arbitral award that was not issued according to the law of Switzerland. 
The fact that the Tribunal has a wider remit is downplayed:

Also, while the Tribunal at times may function as a forum for the resolution of interstate disputes, e.g., when it is called upon to render an opinion as between the United States and Iran under Article II, Sec. 2 of the Claims Settlement Declaration, it primarily is concerned with the resolution of private law rights based on contractual arrangements relating to the provision of goods and services. $^{125}$

This is not entirely satisfactory, because certainly in terms of quantum, the inter-state disputes are significant, if not comparable to the amounts at stake in the claims of nationals. It is in any event an important element of the Tribunal's remit, albeit that in the Gould case, the actual dispute was a claim of a national. It is also questionable whether Tribunal awards can be equated with (other) awards that are not subject to a national law, as the Court did.

This then leads to the discussion on court review at the seat. Even if, for reasons based on the structure of the New York Convention, enforcement can be based on the Convention regardless of the nature, this does not answer the question to what extent Tribunal awards are subject to Dutch arbitration legislation. Although the New York Convention recognizes the fundamental safeguards of due process and public policy if enforcement of an arbitral award is sought, as is duly recognized by the Court of Appeals, such safeguards are similarly of fundamental importance at the seat of the tribunal. A more fundamental approach how to embed mixed arbitration in national law therefore remains important.

\subsection{Mixed arbitration and national law}

Despite the emergence of stand-alone regimes under public international law, which rely on national law for particular purposes, a significant number of mixed arbitrations are still conducted outside such regimes. For example, when one of the parties to a Bilateral Investment Treaty (BIT) or investment agreement is not party to the ICSID Convention, and ICSID arbitration is thus not an option or an alternative, the parties to such agreements must provide for other modalities of arbitration. Occasionally, reference is made to arbitration on the basis of the ICC Rules or other arbitration rules. The most common alternative, however, is arbitration on the basis of the UNCITRAL Rules, possibly because it is perceived to be a truly international regime, drafted by (an organ of) the UN and not linked to a particular institution. The UNCITRAL Rules provide for a number of procedural aspects, including rules relating to the appointment of arbitrators.

Although the UNCITRAL Rules appear effective, they do not operate in isolation from national law. Indeed, Article 1(2) UNCITRAL Rules provides that the 'Rules shall govern the arbitration except that where any of these Rules is in conflict with a provision of the law applicable to the arbitration from which the parties cannot derogate, that provision shall prevail'. Further, national courts may play a role in the 
various interfaces between arbitration proceedings and national courts as were discussed above. $^{126}$

Apart from the limits imposed by public international law on the scope of a state's arbitration legislation, the applicability of national (arbitration) law first and foremost depends on the choice of the legislator. It appears, however, that legislators are generally silent on the scope of national arbitration legislation. For example, the Dutch legislator did not address the applicability of Dutch arbitration law to mixed arbitration when it drafted the Dutch Arbitration Act of 1986 which is still in force. ${ }^{127}$

The legislator's silence is especially notable considering that, as was discussed above, just prior to the introduction of the Act in 1986, the legislator had drafted legislation relating to the qualification of awards from Iran-US C.T. relating to national claims and the applicability of Dutch arbitration law to such claims. Further, while investment arbitration had not yet taken off in the way it has more recently, a number of mixed arbitral awards had come out containing conflicting views on the applicability of national arbitration laws to such proceedings. ${ }^{128}$ While the arbitral tribunals in the ARAMCO case and the TOPCO/CALASIATIC case ruled that these arbitrations were governed by rules of public international law, as discussed above, an arbitral tribunal in a dispute between British Petroleum (BP) and Libya (BP v Libya case) ruled in 1974 that the proceedings in that case were subject to the law of the seat of the tribunal, namely Danish law. The Tribunal observed:

The Tribunal cannot share the view that the application of municipal procedural law to an international arbitration like the present one would infringe upon such prerogatives as a State party to the proceedings may have by virtue of its sovereign status. Within the limits of international law, the judicial or executive authorities in each jurisdiction do, as a matter both of fact and of law, impose limitations on the sovereign immunity of other States within such jurisdictions. Clearly, in some legal systems the degree of control exercised by the courts over arbitral proceedings is greater than in others, and at times extensive. By providing for arbitration as an exclusive mechanism for resolving contractual disputes, the parties to an agreement, even if one of them is a State, must, however, be presumed to have intended to create an effective remedy. The effectiveness of an arbitral award that lacks nationality- which it may if

It appears as if the Dutch legislator overlooked this basic system when proposing the act on the Iran-US C.T.R. in stating that a reference to the UNCITRAL Arbitration Rules reflected the Parties' intent to replace Dutch law.

127 Similarly, the UK Arbitration Act is silent on the scope of the Act in so far as mixed (or for that matter, inter-state disputes are concerned). See, for example, ss 67 and 68 regarding the challenge of awards before the national court, which refer to 'arbitral proceedings' without any qualification or limitation. Please note, however, that according to Delaume, the English Arbitration Act of 1979, which is the predecessor of the current Arbitration Act, and which abolished the 'special case' procedure, 'was enacted for the purpose, among others, of assuring foreign states that, by submitting to arbitration in London, they would no longer have to fear that the submission implied acceptance of the judicial supervisory authority of the English courts'. Delaume (n 119) 689. See also Park (n 6) 38-39.

128 Indeed, Park wrote in 1983 by reference to BP v Libya, ARAMCO and TOPCO/CALASIATIC that ' $[\mathrm{n}]$ o consensus of opinion [existed] on whether arbitration involving a sovereign State may be removed from the control of the lex loci arbitri. Park (n 6) 38. 
the law of the arbitration is international law-generally is smaller than that of an award founded on the procedural law of a specific legal system and partaking of its nationality. Moreover, even where the arbitrators do, as the Tribunal does in this instance, have full authority to determine the procedural law of the arbitration, the attachment to a developed legal system is both convenient and constructive. $^{129}$

Despite the absence of legislative guidance in this respect, case law shows that national courts have meanwhile proceeded to accept jurisdiction on the basis of their national arbitration laws and have responded to requests for support or supervision from parties involved in mixed arbitrations. Case law from the Netherlands, for example, shows that Dutch courts qualify investor-state arbitrations as arbitrations in the meaning of Dutch arbitration law. These cases relate to two phases of arbitral proceedings that were discussed above, namely concerning the constitution of the tribunal (the challenging of an arbitrator) and concerning review of the award (setting aside actions). The former took place almost 10 years ago, in two cases involving the same arbitration and the same arbitrator. The latter took place recently in two distinct investment arbitration proceedings in The Hague.

The challenge decisions related to an investment arbitration between the Republic of Ghana and a Malaysian telecom company, conducted on the basis of A Bilateral Investment Treaty between Ghana and Malaysia and the UNCITRAL Arbitration Rules, and administered by the PCA. The Republic of Ghana challenged one of the appointed arbitrators on the ground that he had been retained as counsel for the purpose of setting aside a mixed arbitration award against the Kingdom of Morocco. This challenge concerns the issue of so-called issue estoppel, whereby someone is challenged not because of perceived financial or material interest, but because of someone's 'wearing of two hats'. Indeed, if someone acts as arbitrator while also acting as counsel in a different case where a similar legal issue plays a role, his or her neutrality can be questioned. This phenomenon is especially relevant in investment arbitration, because the legal issues in investment arbitration are relatively similar and universal and potential overlap of 'interest' is more likely. In addition, the investor/state dichotomy also entails that decisions and, in the view of some, certain decision-makers can be characterized as pro-state or pro-investor. ${ }^{130}$ Such perceived role pattern may further encourage doubts about someone's neutrality and trigger additional challenges.

When both the tribunal and the PCA had rejected Ghana's challenges, Ghana started summary proceedings before the District Court of The Hague and as such

BP Exploration Company (Libya) Limited $v$ Government of the Libyan Arab Republic, Awards of 10 October 1973, 53 ILR 297, p 309. The Tribunal recognized, however, that it was 'not competent to establish conclusively the nationality of its Award, for this can only be decided by the courts of Denmark and of other jurisdictions in which enforcement of the Award may be sought. However, the Tribunal deems this Award to be Danish, and the proceedings have been conducted in a manner designed to be consistent with this view and intent'. On 1 August 1974, the Tribunal denied a request from BP to partially set aside its award because under Danish law an arbitral tribunal is not competent to re-open the proceedings to deal with such requests.

130 In commercial cases, it is much more difficult to discern clear lines in particular because the legal issues are more diffuse and more numerous. 
effectively 'appealed' the PCA's decision. The District Court of The Hague decided that it would uphold Ghana's challenge unless the arbitrator involved would step down as counsel in the setting aside proceedings against the Kingdom of Morocco within 10 days, ${ }^{131}$ which he did. A subsequent challenge before the District Court of the Hague on the basis that the arbitrator involved had been involved in decisions of the tribunal before his stepping down as counsel was rejected. ${ }^{132}$

The case is noteworthy for various reasons. First, the District Court qualified the arbitration between Ghana and the Malaysian telecom company as an international arbitration in the meaning of Dutch arbitration law and ruled that it had jurisdiction to hear this challenge since the Tribunal was seated in The Hague. Although sovereign immunity could not play a role in these proceedings since it was Ghana which sought a decision from the Dutch court, the applicability of Dutch arbitration law and the jurisdiction of the District Court of The Hague were regarded as self-evident by all parties involved. Secondly, it is noteworthy that the District Court came to a different conclusion on the merits of the challenge request than the PCA, which underlines the significance of a supervisory role of a national court. Thirdly, decision of the District Court was unorthodox since it made its decision conditional on the arbitrator's stepping down as counsel in the parallel proceedings. Although this approach may be seen as creative and has since been followed elsewhere, ${ }^{133}$ it is not obvious that it was within the Court's jurisdiction to make such condition since it related to his role in a different procedure.

The second set of cases involved recent requests for setting aside of investment arbitration awards rendered by tribunals having their seat in the Netherlands, namely Republic of Ecuador $v$ Chevron Corporation \& Texaco Petroleum Company, ${ }^{134}$ and Adria $v$ Republic of Croatia. ${ }^{135}$ While it was Ecuador which invoked the Court's supervision in the former case and thus clearly accepted the applicability of the Netherlands' arbitration legislation and the jurisdiction of the courts of the Netherlands, it was Adria which instigated the proceedings against Croatia in the latter proceedings. Croatia, however, proceeded on the merits and did not object to the applicability of Dutch arbitration law as such and the ensuing jurisdiction of the District Court of The Hague. Similar to its above-mentioned 2004 challenge decision, the District Court simply considered in both cases that the parties agreed that

ibid.

133 See, for example, the NAFTA case Vito G Gallo $v$ Government of Canada (14 October 2009), in which the Deputy Secretary-General of ICSID rejected the claimant's request for an arbitrator's disqualification, but ordering him within 7 days to choose between continuing to advise Mexico, or continuing to serve as arbitrator <http://italaw.com/documents/Gallo-Canada-Thomas_Challenge-Decision.pdf> (accessed 5 February 2015).

134 District Court of The Hague, Judgment of 2 May 2012 (Republic of Ecuador v Chevron Corporation (USA) and Texaco Petroleum Company), ECLI:NL:RBSGR:2012:BW5493. The District Court rejected Ecuador's request to set aside the arbitral award on the basis of lack of jurisdiction and excess of powers. The District Court's judgment was upheld by the Court of Appeals (Court of Appeals of The Hague, Judgment of 18 June 2013 ECLI:NL:GHDHA:2013:1940). The judgment of the Court of Appeals was subsequently upheld by the Supreme Court of The Netherlands, Judgment of 26 September 2014 (ECLI:NL:HR:2837).

135 District Court of The Hague, Judgment of 15 August 2012 (Adria Beteiligungs GmbH v Republic of Croatia), ECLI:NL:RBSGR:2012:BX6825. 
the place of arbitration was in the Netherlands and held that therefore the provisions of the Dutch arbitration law were indeed applicable.

While the parties in the above-mentioned cases did not object to the involvement of the Dutch courts in their mutual disputes, ${ }^{136}$ the involvement of the courts of England was questioned in relation to a request for setting an investment arbitration award in 2005. ${ }^{137}$ When Ecuador seized the High Court of Justice in 2004 in order to set aside an award rendered by an arbitral tribunal on the basis of a BIT between the US and Ecuador and the UNCITRAL Arbitration Rules, Occidental Exploration and Production Company argued that the doctrine of non-justiciability prevented the courts of England to hear such dispute. The doctrine of non-justiciability 'establishes a general principle that the Municipal courts of England and Wales do not have the competence to adjudicate upon rights arising out of transactions entered into by independent sovereign states between themselves on the plane of international law. ${ }^{138}$

It is notable that the jurisdiction of the English courts as such was undisputed. Although this case was 'the first time that an arbitration award rendered pursuant to a Bilateral Investment Treaty [had] been brought before the English Courts', ${ }^{139}$ the courts of England were deemed to have jurisdiction by virtue of Article 67 of the 1996 Arbitration Act. The High Court held that it was undisputed that the seat of the arbitration was London and since 'Part One of the Arbitration Act 1996, (which includes section 67), [applied] to arbitrations "where the seat of the arbitration is in England and Wales and Northern Ireland"... the court [had] jurisdiction to determine Ecuador's challenge to the Award of the Tribunal as to its substantive jurisdiction'. ${ }^{140}$ The High Court (Aikens J) observed that Article 67 of the 1996 Arbitration Act provided a sufficient 'foothold' in national law for a ruling to be given on international law and that there was 'nothing in the 1996 Act to say that it is not available in certain circumstances. ${ }^{141}$ Ultimately, the Court decided that the doctrine of nonjusticiability did not prevent it to decide on Ecuador's request. After all, Aikens J argued, 'it would be odd if the English court could not do so, once the Tribunal had

136 The Ecuador case, in particular, is a good example why apart from dogmatic reasons, court control over mixed arbitrations is not unproblematic. Under Dutch arbitration law, court review is deliberately kept to a minimal level. This restraint does not, however, extend to the court's review of an arbitrator's jurisdiction. In the Ecuador case, the setting aside action involved a number of complicated issues including the temporal scope of investments covered by the BIT. This aspect of the tribunal's jurisdiction required a close analysis of the relevant BIT. Whereas the District Court was of the opinion that the temporal scope of the investment was not be part of the jurisdictional review as such, and therefore only subject to limited review, the Court of Appeals fully reviewed the question to what extent the tribunal had jurisdiction to hear Chevron's claim. The Supreme Court upheld the Court of Appeals judgment, among other reasons, because it qualified the BIT between Ecuador and the United States as 'foreign law', ie law which is not applicable in the Dutch legal order. Under Dutch law, the interpretation of foreign law cannot be challenged in cassation.

137 High Court of Justice, Queen's Bench Division, before Mr Justice Aikens, Judgment of 29 April 2005 (The Republic of Ecuador v Occidental Exploration and Production Company), 2005 EWCA 774.

138 High Court, Ecuador v Occidental, ibid para 1.

139 ibid para 3.

140 ibid para 43. See also paras 35 and 38 (for the arguments of the parties), 64, and 71-72.

141 ibid, para 76. 
chosen London as the seat of the arbitration and had therefore made this procedure subject to Part 1 of the 1996 Act'. ${ }^{142}$

The Court of Appeal confirmed this decision ${ }^{143}$ and in doing so distinguished an (investment) arbitration carried out on the basis of the UNCITRAL Rules from ICSID proceedings. Whereas in the case of ICSID there is no recourse to the English Court under the Arbitration Act of $1996,{ }^{144}$ no such limitation applied in relation to UNCITRAL arbitrations. ${ }^{145}$ According to the Court of Appeal, there was no reason 'why any arbitration held pursuant to [an agreement to arbitrate between an investor and a State], or any supervisory role which the court of the place of arbitration may have in relation to any such arbitration, should be categorized as being concern with "transactions between States" so as to invoke the principle of nonjusticiability. ${ }^{146}$

In a recent US Supreme Court decision, BG Group PLC v Argentina, ${ }^{147}$ the Court also had the opportunity to consider an investment arbitration award. Whereas this was not the first time the Court was faced with this kind of arbitration, this particular case was significant because it related to the fundamental question of the nature and scope of review of a tribunal's ruling on the validity of an arbitration agreement, and whether the requirement first to submit a dispute to local litigation should be considered a component of the consent to arbitrate or merely constitutes a procedural precondition to arbitration. The difference is relevant because the former requirement justifies a de novo review, whereas the latter is primarily the responsibility of the arbitrators. In answering this question, the Court held that, contrary to the view expressed by the US Government, it did not accept that the matter should be treated differently because the arbitration agreement was contained in a treaty. Rather, it should be treated as a matter of normal contract interpretation, as 'a treaty is contract, though between nations'.

In their dissent, Roberts and Kennedy, on the other hand, emphasized that the consent to arbitration in this case was conditional upon the requirement to initiate court litigation, and that the nature of the obligations a sovereign incurs in agreeing

142 ibid, para 86.

143 Court of Appeal, before Lord Phillips of Worth Matravers, Mr Lord Justice Clarke and Lord Justice Mance, Occidental Exploration \& Production Company $v$ The Republic of Ecuador, 9 September 2005, 2005 EWCA Civ 1116.

144 See the Arbitration (International Investment Disputes) Act 1966, s 3(2).

145 Ecuador relied on a number of foreign cases in which mixed arbitrations had been the subject of court control, notably three NAFTA cases (United Mexican States v Metalclad (2001) 5 ICSID Rep 236; United States of Mexico v Martin Roy Feldman Karpa, 11 January 2005; AG of Canada v SD Myers Inc, 13 January 2004) and the Swedish decision Czech Republic v CME Czech Republic BV (2003) 42 ILM 919, where the Svea Court of Appeals in Sweden reviewed an issue of jurisdiction of arbitrators appointed to determine an investment dispute under a BIT between the Czech Republic and the US.

146 Court of Appeal (Lord Justice Mance) para 41. Please note one of Ecuador's arguments in appeal that it would be an infringement of the right of access to the courts under article 6 of the European Convention on Human rights, if the issue of the arbitrators' jurisdiction could not be raised under s.67 of the Arbitration Act 1996'. The Court of Appeal found it 'unnecessary to go into this very briefly argued suggestion, which has on its face some implausibility in the case of a State claiming to be protected in respect of its supposed human rights'. ibid para 49.

147 Supreme Court of the United States, BG Group plc, v Republic of Argentina, 5 March 2014, No 12-138, 572 US (2014), through < www.supremecourt.gov> (accessed 5 February 2015). 
arbitration confirms the significance of this condition, which goes beyond a mere procedural formality. Neither the main opinion of the Court nor the dissent, however, contains a comparable discussion to the 'non-justiciability' discussion as in the UK Court of Appeal decision in Occidental $v$ Ecuador.

\subsection{Conclusion}

It follows from the foregoing that, in order to establish the applicable lex arbitri to mixed arbitrations, one must distinguish between mixed arbitrations conducted within the framework of a stand-alone regime and mixed arbitrations which are conducted outside such regimes. ${ }^{148}$ The applicable lex arbitri to the former category is determined by the treaty which underlies such regime, such as the ICSID Convention for ICSID and the Algiers Accords/Claims Settlement Declaration for the Iran-US C.T. These regimes are thus based and governed by rules of public international law but rely on national law for enforcement purposes. As such these regimes are governed by a hybrid regime consisting of both public international law and national law.

The applicable lex arbitri to the latter category, however, is not self-evident. ${ }^{149}$ On the one hand, some arbitral tribunals have ruled that in view of the sovereignty of the state involved in the arbitration proceedings, such proceedings are governed by rules of public international law. On the other hand, other tribunals have ruled that mixed arbitrations are governed by national arbitration laws. Although both views are based on sound legal arguments, ${ }^{150}$ an arbitral tribunal cannot, as a matter of principle, determine the applicability or non-applicability of national arbitrational laws.

The relatively recent judgments of Dutch and English courts, which have been discussed above, appear to be more telling and may be indicative for national courts in other jurisdictions faced with similar disputes. The judgments suggest little reluctance on the part of these courts to qualify mixed arbitrations as arbitrations in the meaning of their respective arbitration acts and thus accept jurisdiction, despite the absence of clear statutory guidance.

Further, it appears that also the Dutch legislator has meanwhile accepted the applicability of Dutch arbitration legislation to investment arbitrations. This follows

149 Dolzer and Schreuer appear to take the jurisdiction of national courts for granted in non-ICSID arbitrations. In such arbitrations, 'the normal way to challenge an award is through national courts. This is done in the courts of the country in which the tribunal has its seat or by the courts charged with the tasks of enforcing the award.' R Dolzer and C Schreuer, Principles of International Investment Law (2nd edn, OUP, Oxford, 2012)300, 310.

150 See, for example, the discussion of the ARAMCO, TOPCO/CALASIATIC, LIAMCO and BP v Libya cases, and the importance of the 'domestic nature' of the award for enforcement purposes, by Delaume. Delaume (n 119) 688-93. See also the rebuttal of the arguments made in favour of 'localizing the procedural law' (BP v Libya) by Von Mehren and Kourides, both of whom were of counsel to TOPCO in the TOPCO/CALASIATIC case, in which case the tribunal chose to 'internationalize' the arbitration, as was discussed above. They observe that the localization of an award for enforcement purposes has only limited value in view of the difficulties in many states to execute an award against the property of sovereign states. R B von Mehren and P N Kourides, 'International Arbitrations between States and Foreign Private Parties: The Libyan Nationalization Cases' (1981) 75 Am J Int L508-9. 
from the legislative process of the revision of the Dutch Arbitration Act. Whereas an explicit provision on the scope of the Act is absent, the Minister of Justice's reply to questions raised in Parliament is unequivocal in confirming that the Act extends to investment arbitration. ${ }^{151}$ In view of the above-mentioned cases, this view would confirm existing judicial practice. Still, in light of the above-mentioned developments and in view of the aborted legislation in relation to the Iran-US C.T. legislation, which suggested a more nuanced approach, more explicit guidance would have been appropriate.

\section{CONCLUSION}

The practice of international arbitral tribunals and the ICJ confirms that inter-state arbitration is subject to public international law, which effectively constitutes the lex arbitri of inter-state arbitration. General rules of customary international law limit the adjudicative jurisdiction of a state hosting an inter-state arbitration tribunal and arguably the prescriptive jurisdiction of that state. As a corollary, inter-state arbitration can only be subjected to the national courts of the host state or its national arbitration legislation, if the host state and the disputing parties explicitly agree thereto, which appears to be an academic option.

By contrast, the lex arbitri pertaining to mixed arbitration will generally be a national law. Here, a distinction should be made between mixed arbitrations conducted within the framework of a stand-alone regime and mixed arbitrations which are conducted outside such regimes. The former, such as ICSID and the Iran-US C.T., have their own stand-alone systems and are subject to different hybrid regimes consisting of a mixture of public international law and national law.

Although older arbitral case law demonstrates support for the notion that mixed arbitrations are governed by public international law, the more recent view, certainly when it comes to investment arbitration is that mixed arbitrations, which are not governed by a stand-alone system, are governed by national arbitration laws. As such, they are subject to support and supervision by national courts. This follows from case law from the United Kingdom, the Netherlands and the US, and has recently been confirmed explicitly in the Dutch legislative process.

Therefore, if the EU and its contracting parties choose to include an ISDS mechanism in the envisaged TTIP or any other FTA which is currently being negotiated, it will be important for the negotiators to consider the relevance of the lex arbitri. Such arbitrations may very well be subject to national arbitration law and the supervision of national courts as a matter of principle, if the EU and its partners do not establish a stand-alone regime like ICSID or the Iran-US C.T.

From the 'public consultation on modalities for investment protection and ISDS in TTIP', which was released on and opened for the public on 27 March 2014, ${ }^{152}$

151 Nota naar Aanleiding van het Verslag (Aide-Mémoire following parliamentary discussion), Kamerstukken II, 2013/14, 33611, no 5, p 3. See for a more general discussion of the revision of the Dutch Arbitration Act, Jacomijn van Haersolte-van Hof, 'Revision of the Dutch Arbitration Act: Making the Netherlands an Even Better Place for Arbitration' (2014) 31 J Int Arbitration 425-437.

152 Public consultation on modalities for investment protection and ISDS in TTIP, available from 27 March 2014 till 6 July 2014 through <ec.europa.eu/trade/policy/in-focus/ttip/> and <trade.ec.europa.eu/ consultations $/>$ (accessed 5 February 2015). In the accompanying 'Consultation notice', the European 
it appears that the EU indeed aims for a stand-alone regime in the TTIP. This would follow from the EU's objective to establish an appellate mechanism in the TTIP. According to the European Commission, such mechanism will

help ensure consistency in the interpretation of TTIP and provide both the government and the investor with the opportunity to appeal against awards and to correct errors. This legal review is an additional check on the work of the arbitrators who have examined the case in the first place. In agreements under negotiation by the EU, the possibility of creating an appellate mechanism in the future is envisaged. However, in TTIP the EU intends to go further and create a bilateral appellate mechanism immediately through the agreement. ${ }^{153}$

The envisaged mechanism appears to be similar to the appellate mechanism within the framework of the World Trade Organization and is no doubt revolutionary when it comes to investment arbitration. However, the consultation and the reference texts which are included in the consultation document, and which are 'taken from other investment agreements and from the approach developed in the EU-Canada (CETA) negotiations' are silent as to the possibility of challenging (appellate) awards and on the enforcement of awards. Therefore, if the envisaged mixed arbitration system is indeed to function as a stand-alone regime, independent from national arbitration laws and without interference from national courts, more specific regulations in the TTIP and other FTAs will be necessary.

Commission explains that it has decided to consult the public in the EU, ' $[\mathrm{g}]$ iven the strong public interest in this issue', 'on a possible approach to investment protection and ISDS that contains a series of innovative elements (...) that the EU intends to use as the basis for the TTIP negotiations'. The consultation does not only relate to substantive provisions for investment protection but relates to transparency requirements, relationship to domestic courts, codes of conduct for arbitrators, reducing the risk of frivolous claims and interpretation of the agreement. 